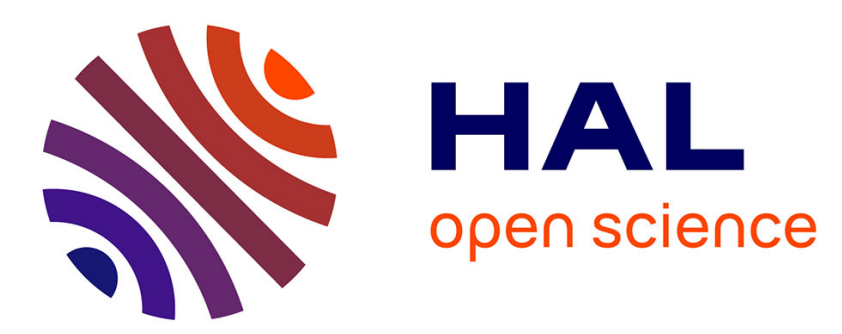

\title{
Habitat fragmentation experiments on arthropods: what to do next?
}

Elvire Bestion, Julien Cote, Staffan Jacob, Laurane Winandy, Delphine

Legrand

\section{- To cite this version:}

Elvire Bestion, Julien Cote, Staffan Jacob, Laurane Winandy, Delphine Legrand. Habitat fragmentation experiments on arthropods: what to do next?. Current Opinion in Insect Science, 2019, 35, pp.117-122. 10.1016/j.cois.2019.07.011 . hal-02340183

\section{HAL Id: hal-02340183 \\ https://hal.science/hal-02340183}

Submitted on 30 Oct 2019

HAL is a multi-disciplinary open access archive for the deposit and dissemination of scientific research documents, whether they are published or not. The documents may come from teaching and research institutions in France or abroad, or from public or private research centers.
L'archive ouverte pluridisciplinaire HAL, est destinée au dépôt et à la diffusion de documents scientifiques de niveau recherche, publiés ou non, émanant des établissements d'enseignement et de recherche français ou étrangers, des laboratoires publics ou privés. 


\title{
Habitat fragmentation experiments on arthropods: what to do next?
}

\author{
Elvire Bestion ${ }^{1,}$, , Julien Cote ${ }^{2}$, Staffan Jacob ${ }^{1}$, Laurane Winandy ${ }^{2}$, Delphine Legrand ${ }^{1}$
}

Current Opinion in Insect Science, 2019, 35:117-122, doi: 10.1016/j.cois.2019.07.011

\author{
${ }^{1}$ CNRS, Université Toulouse III Paul Sabatier, UMR 5321, Station d'Ecologie Théorique et Expérimentale, 2 route du CNRS, \\ 09200 Moulis, France \\ 2 CNRS, Université Toulouse III Paul Sabatier, UMR 5174, Laboratoire Évolution \& Diversité Biologique, 118 route de \\ Narbonne, 31062 Toulouse, France.
}

*Correspondence to: e.bestion@outlook.com

\begin{abstract}
Habitat fragmentation has the potential to influence ecological and evolutionary dynamics in various ways. Fragmentation experiments explore these multiple influences and the underlying mechanisms. We review experiments used in arthropods and highlight gaps in biological focus, methodology and questions addressed. While the consequences on community structure were often reported, fewer studies focused on ecosystem functions and evolutionary processes, with striking gaps on genetic and eco-evolutionary dynamics. Regarding fragmentation components, matrix quality was often overlooked while inter-patch (and source-patch) distance was the most studied component. The identified gaps outlined our need to study fragmentation at different time-scales, and on teasing apart the respective roles of each fragmentation component on each eco-evolutionary process.
\end{abstract}

Keywords: habitat fragmentation, arthropod, insect, review, experiment, eco-evolutionary dynamics, species traits

\section{INTRODUCTION}

Habitat loss and fragmentation profoundly alter biodiversity [1], although some debated data recently suggested potential benefits of fragmentation per se [2-4]. Habitat fragmentation involves the transformation of large expanses of habitat into a number of smaller patches of smaller total area, isolated from each other by a matrix of altered habitat [5]. It involves the conjunction of four components: (a) reduction in habitat amount, (b) increase in the number of habitat patches, (c) decrease in patch size, and (d) increase in patch isolation [6]. Consequently, the edge-to-core habitat ratio also increases with fragmentation [7]. The relative importance of these components on biodiversity may vary between landscapes, making the investigation of fragmentation impacts complex. This investigation is further hampered by the confounding effects on biodiversity between fragmentation per se (i.e., the breaking apart of habitat, controlling for changes in habitat amount, [6]) and reduction in habitat amount. As habitat fragmentation is inherently linked to habitat loss in most landscapes, there is a correlational structure between the effect on biodiversity attributable to habitat loss and to fragmentation per se [8]. Further, fragmentation may have confounding, synergetic and/or antagonist effects with other global change aspects such as urbanisation, climate change or biological invasions [9-11]. Fragmentation effects might also be nonlinear but increase exponentially after a threshold of habitat loss (e.g. [12,13] but see [14]), which might be especially relevant given the dire predictions for future habitat degradation [15]. Such complexity pleads for using experimental approaches to better estimate the relative consequences of different fragmentation components [16], the interactive effects with other abiotic and biotic drivers and the effects at different spatio-temporal scales, potential sources of discordance in results [3]. While "natural experiments" (sensu Diamond 1986 [16], i.e. field observations) escape spatio-temporal scale issues and benefit from higher realism and applicability, laboratory and field manipulative experiments (Hurlbert 1984 [17]) allow to disentangle between the effects of correlated components 
fragmentation, test for interactive effects of other ecological factors, and tackle mechanisms behind biodiversity changes. Here, we aim at providing an overview of the current experimental approaches testing for habitat fragmentation consequences in arthropods.

Arthropods constitute a major part of biodiversity [18] and provide fundamental ecosystem services [19]. As small ectotherms, arthropods might be especially sensitive to the accumulation of physical, biotic and climatic dispersal barriers created by fragmentation [20]. Further, many arthropods depend on multiple habitats (aquatic, terrestrial or aerial) during their ontogeny, imposing distinct constraints on movement. Unfortunately, the number of fragmentation studies on arthropods is not proportional to their biological importance and sensitivity to fragmentation $[2,21]$.

We created a data base of existing experiments on habitat fragmentation on arthropods using a systematic review of the literature. From this database, we aimed to provide a full picture of how fragmentation has been manipulated in arthropod experiment by classifying the taxa, the biological level, the fragmentation components manipulated and the response variables. We also aimed to identify gaps in the questions addressed and potential shortcomings in experimental approaches. We searched Web of Sciences with experiment* AND fragment* OR main fragmentation components OR metasystem type (see Supplement for exact search), yielding 5865 articles, of which 212 were finally included (Fig S1). Criteria for inclusion comprised (a) study involves arthropods, (b) is a manipulative experiment (sensu $[17,22]$ ) performed through landscape manipulation in the field or in the laboratory, and (c) focuses on one or more of the above defined fragmentation components, irrespectively of their distinction of fragmentation per se. Natural experiments (sensu [16]) without landscape manipulation per se (e.g. translocation between landscapes) were therefore excluded. Our aim was to provide a full picture of how fragmentation has been manipulated in arthropod experiments. The identified gaps were used to propose guidelines to improve our understanding of fragmentation impacts.

\section{BIOLOGICAL FOCUS OF STUDIES}

A third of the studies focused on large arthropod communities, and a quarter on a single species (Fig 1A). The most investigated insect orders were Coleoptera, Hymenoptera, Lepidoptera and Hemiptera, and the most investigated non-insect classes where Arachnida and Malacostraca (Fig S2A). Formicidae, Apidae, Aphididae and Delphacidae were well represented families (Fig S2B); Prokelisia crocea (planthopper), Anagrus columbi (fairyfly) and Junonia coenia (butterfly) were the most studied species. Surprisingly, very few studies used model species like Drosophila, Culex or Bombyx (but see $[23,24]$ ), at the exception of bees and, to a lesser extent, Daphnia.

Aquatic systems were particularly neglected as well as their interface with terrestrial environments (Fig 1, but see [25]). Insects with complex lifecycles (e.g. dragonflies) might undergo different ecoevolutionary pressures induced by fragmentation during ontogeny, potentially affecting ecological dynamics at a regional scale even when fragmentation occurs at very local scales.

More than half of the studies focused on the community level, and drew general inferences mostly on fragmentation effects on species richness and abundance. While understanding how fragmentation modifies interaction strengths is crucial to assess its impacts on community dynamics, very few studies tackled species interactions, in particular competitive strengths (Fig S3B). Within species, roughly equal number of studies focused on population abundance and dispersal or movement. Fewer studied focused on other phenotypic traits, and only one study on genetics (Fig S3C). This points out a lack of evolutionary consideration, with $1 \%$ of studies explicitly testing evolutionary processes. 


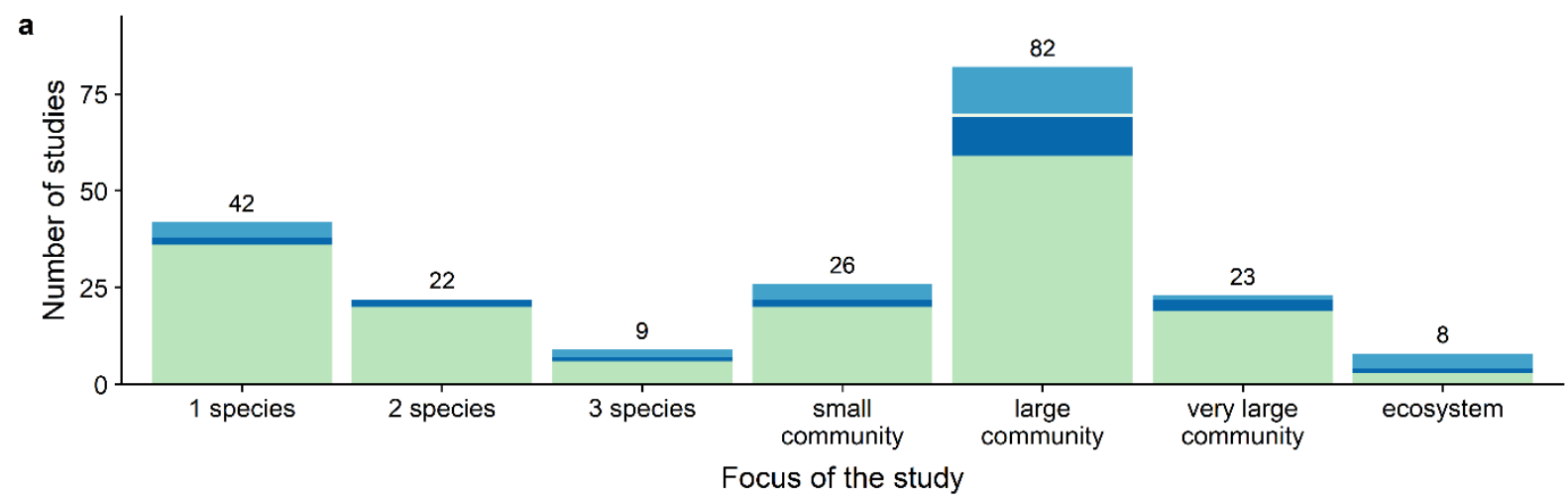

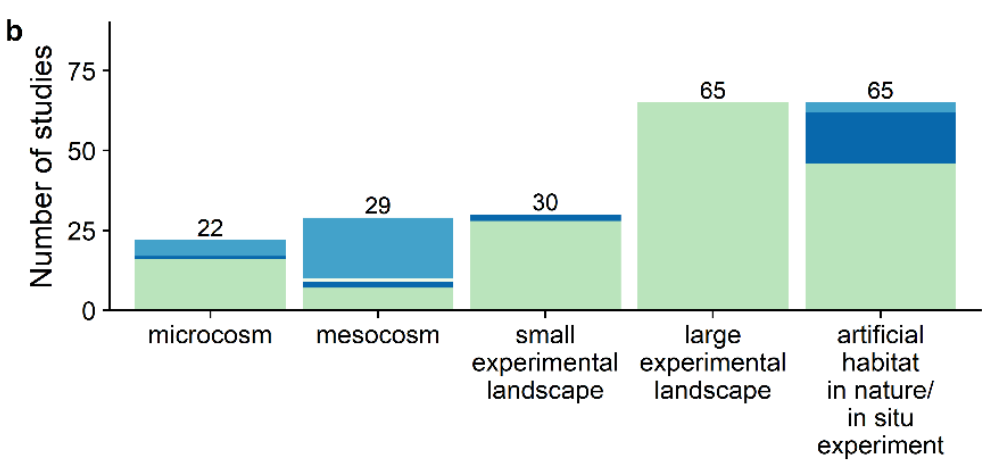

Type of experimental system

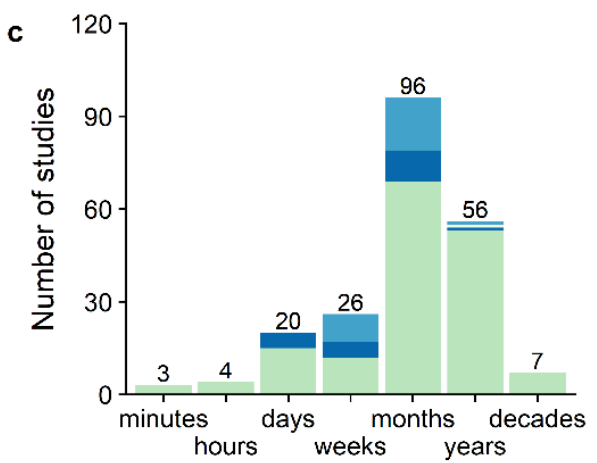

Duration of the study
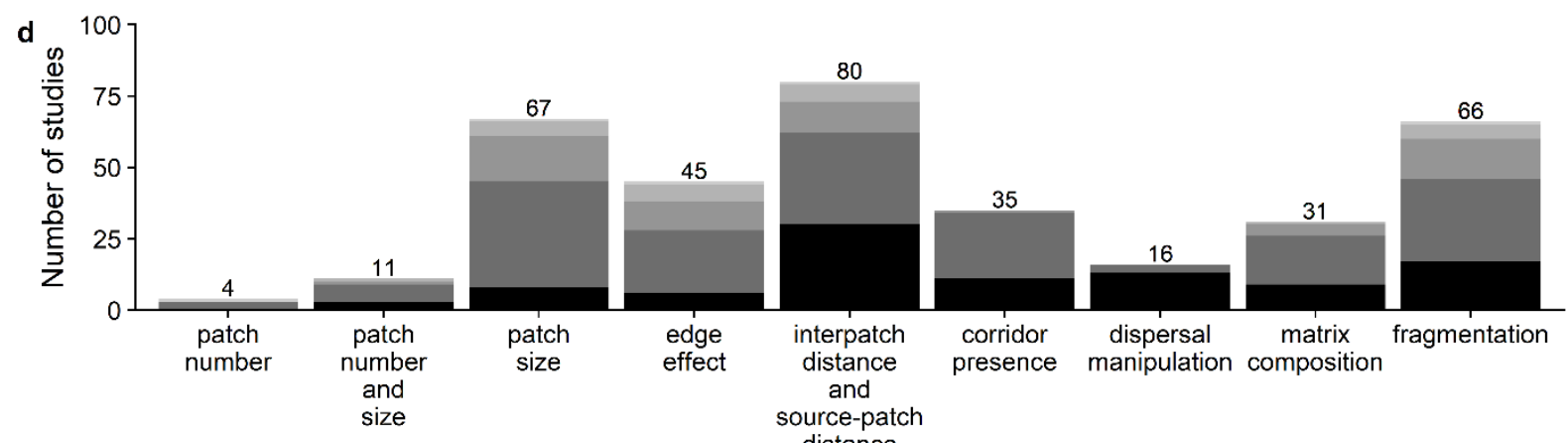

distance

$$
\begin{gathered}
\text { and } \\
\text { source-patch }
\end{gathered}
$$

distance

Fragmentation component

$\begin{array}{lll}\text { Biological system } & \begin{array}{l}\text { freshwater } \\ \text { freshwater/terrestrial }\end{array} \text { marine } \\ \text { terrestrial }\end{array}$

Number of components investigated

\section{Figure 1: Number of studies by biological focus, type and duration of experiment} and fragmentation components.

(a) Biological focus of the study. Small communities are $<10$ species, large communities $<100$ species and very large communities $>100$ species, the ecosystem category is for studies focusing on ecosystem functions. (b) Type of experimental setting. Microcosms $\left(<1 \mathrm{~m}^{2}\right)$ are divided into indoor microcosms (16 studies), outdoor microcosms (1 study), and undefined (5 studies). Mesocosms (>1 $\mathrm{m}^{2}$ ) are divided into indoor mesocosms (3 studies) and outdoor mesocosms (26 studies). Small experimental landscapes are $<1$ ha, and large $>1$ ha (see Supplement for discussion of area). The last category involves studies manipulating landscape features in natura. (c) Duration of the study. (d) Type of fragmentation components investigated. Notice that the total number of studies for this plot is more than 212 as several studies focus on more than one fragmentation component. Also notice that "fragmentation" defines studies where all components vary together, for instance "continuous vs fragmented". 
While arthropods are crucial for many ecosystem functions (e.g., nutrient cycling [19]) themselves affected by fragmentation [26], only $5 \%$ tackled ecosystem functions or related relevant traits like biomass and decomposition rate (Fig 1A, Fig S3C).

\section{EXPERIMENTAL SETTINGS AND FRAGMENTATION COMPONENTS STUDIED}

Forty-four percent of the studies made use of small or large experimental landscapes, 30\% manipulated landscape features in natura and only $24 \%$ used micro- or mesocosms (Fig 1B). Study duration varied from minutes to decades, but was predominantly months (Fig 1C, see supplement for discussion on generation times). Having decade-long studies such as [27-29] is an asset as time lags are crucial in understanding the effects of fragmentation, with potentials for extinction debts arising [30].

Half of the studies were designed to isolate the effect of one component (e.g. patch number, interpatch distance, matrix composition), the others investigated 2 or more components (Fig 1D) with more than half manipulating all fragmentation components at the same time. The latter mainly contrasted two fragmentation levels (continuous/fragmented) while fewer used 3 levels (continuous/slightly fragmented/highly fragmented) or more (Fig S4A), despite the fact that fragmentation processes are non-linear $[12,13]$. Patch size and edge effect were frequently studied, in comparison to the number of patches. Connectivity was studied through the manipulation of interpatch distance, corridor presence or dispersal manipulation, but rarely through matrix composition modification (Fig 1D).

Interactions between fragmentation and other aspects of global changes can represent deadly cocktails for biodiversity [9]. However only $6 \%$ of experiments also manipulated other aspects of global change (temperature, pollution, invasive species). More generally, only $33 \%$ and $13 \%$ of the studies manipulated or quantified the biotic quality (mainly vegetation composition) and the abiotic quality (e.g. salinity, nutrients) of patches respectively.

As previously outlined [31], we observed a trade-off between ecological realism and the number of experimental replicates within studies (Fig S4B). This trade-off is further compounded when multiple studies use the same experimental landscape, thus decreasing the ecological replication among ecosystems. Indeed, half of the studies on large experimental landscapes hinged on four projects only (Savannah River Site, Miami research center, Wog Wog or BDFFP project). On the one hand, the detailed consequences of fragmentation on well-known experimental systems provide unique comparative power that deserves special attention. On the other hand, the low ecological replication might lead to over-generalising results potentially idiosyncratic and dependent on specific features of the studied systems. Particularly, most of the studies focus on forests or grasslands [31] and are located in temperate zones [21]. Results that apply to these ecosystems might not be extendible to other regions and/or ecological biomes. We urge to increase the ecological replication of experimental settings, especially adding new large/small experimental systems in diverse regions and ecological biomes including at the terrestrial/aquatic interface.

\section{WHAT TO DO NEXT?}

Despite a wide breadth of experimental studies either directly- or indirectly-focused (e.g. metasystem's literature) on habitat fragmentation, we confirmed previous identified gaps, and highlighted unexpected ones in the biological focus, questions, fragmentation components studied (Fig 2, Table S1A-C) and methodology used (Table S1D). We hereafter suggest improvements of experimental studies. As our goal was not to compare experimental and non-experimental studies, identified gaps may also (and often do) apply to non-experimental studies. 


\section{Type of biome}

aquatic

terrestrial

aquatic-terrestrial interface

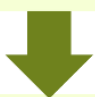

\section{Fragmentation : \\ - components}
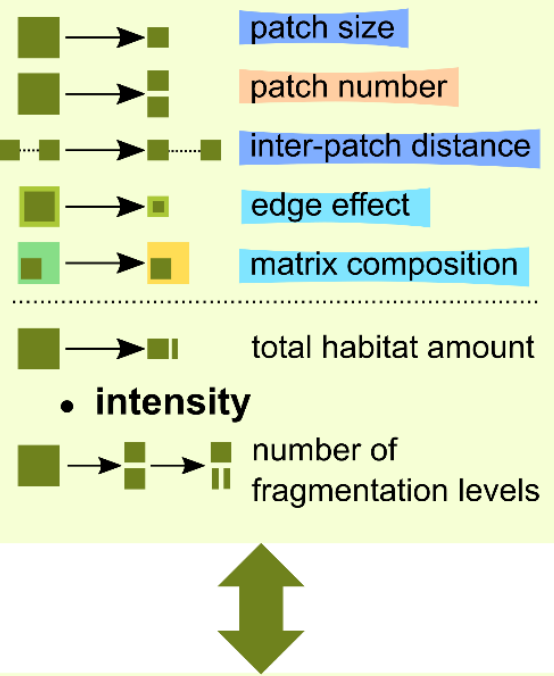

\section{Additional forcing agents}

temperature

pollution

invasive species

\section{Legend \\ $<10$ studies \\ 30-59 studies \\ 10-29 studies}

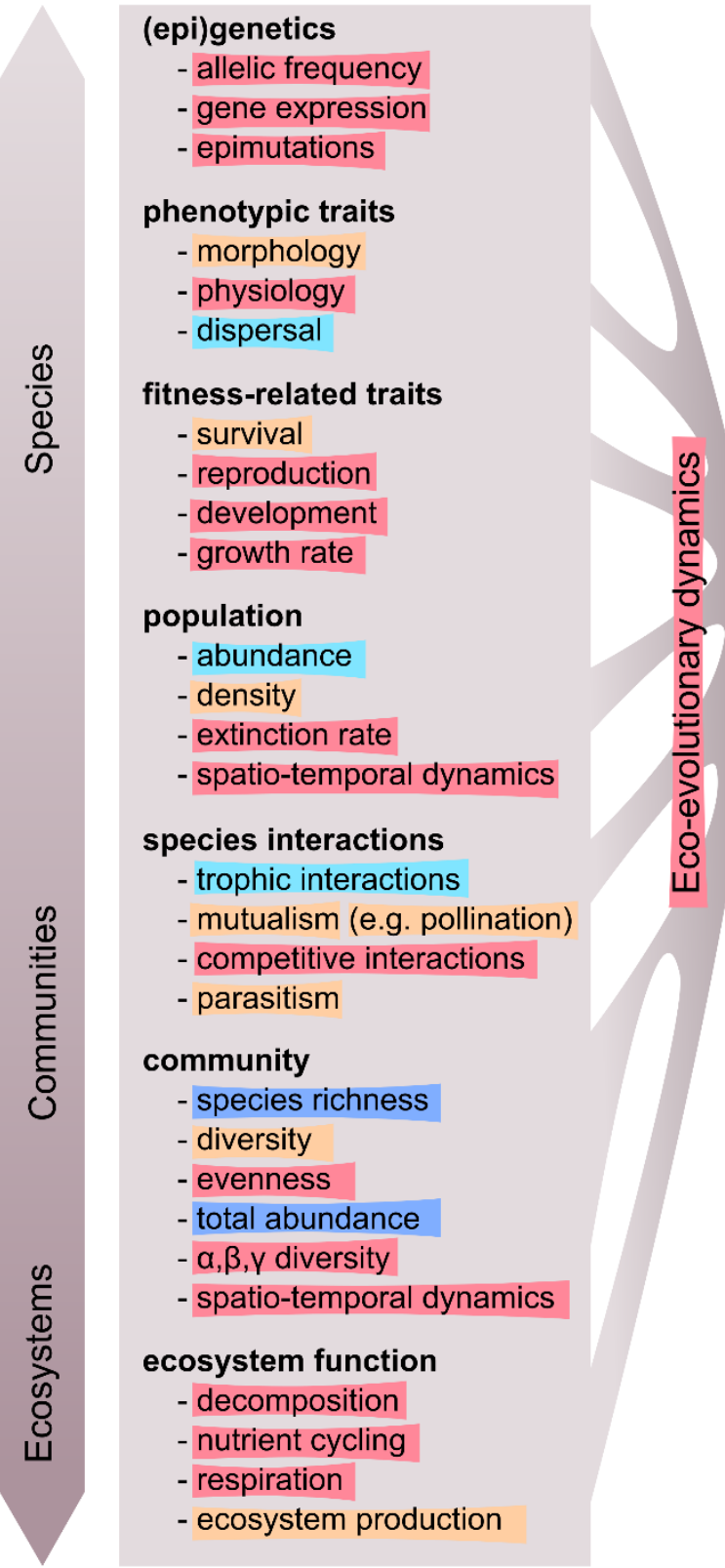

Figure 2: Summary of the potential impacts of fragmentation components on different levels of biodiversity, and gaps in our understanding of these impacts.

Concepts are underlined in different colours depending on the number of studies in which they are investigated. Concepts underlined in red represent strong gaps in our understanding (see Table S1 for a more detailed analysis of the gaps), with below 10 studies tackling them. Concepts in orange were tackled by 10-29 studies, in light blue by 30-59 studies and in dark blue by $>60$ studies. Notice that for each biological level, we underline only a few aspects (e.g. under phenotypic traits, we detail morphology but not behaviour).

Our main takeaway is that a large portion of experiments usefully describe changes in community structure, but rarely examine the underlying changes in species interaction and the subsequent changes in community dynamics. Such gaps on species interactions were highlighted 20 years ago [31], with some improvements in the recent years for arthropods (Fig S5). We also lack studies on ecosystem functions such as decomposition rate, which is key to nutrient cycling. Future fragmentation experiments on arthropods should therefore shift from community descriptive 
investigation to the study of species interactions and consequences on ecosystem functions. Dedicated fragmentation platforms should help to achieve these goals [32,33]. Although a significant number of studies focused on the species level, the evolutionary consequences of fragmentation were largely ignored, with the exception of dispersal-related studies, which were pointed out as a gap 20 years ago [31] that have been partly filled since (Fig S5). Therefore, the respective roles of adaptation, drift, plasticity or mutation in the response to fragmentation are little known in arthropods. This knowledge is however crucial to correctly interpret patterns and predict biodiversity changes. This limited interest for the evolutionary consequences of fragmentation explains why theoretical predictions about the role of fragmentation in eco-evolutionary feedbacks remain untested [34]. Future studies should thrive to understand how species traits, but also genomes, evolve with fragmentation in complex biological settings where interacting species can jointly coevolve. The development of omics and/or use of arthropod models such as Drosophila or Daphnia should help to achieve such mechanistic goals. Coupling these experimental studies with both theoretical models and validation in the field should help better understanding how eco-evolutionary processes affect arthropod biodiversity.

Regarding fragmentation components, matrix composition remains poorly studied since Debinski and Holt's review [31]. While matrix is at the core of fragmented landscapes [26,35], its resistance, a fundamental parameter to assess functional connectivity [36], is understudied, and has been called for. We also call for an increase in the type of ecological biomes studied with large replication within landscapes, and for more numerous levels of habitat fragmentation with continuous landscapes as controls. Finally, we urge for the integration of other components of global changes in fragmentation experiments. Climate change, pollution and the spread of invasive species can often co-occur with habitat fragmentation. Experimenters should aim at assessing interactions and eco-evolutionary consequences of these multiple global change drivers.

To conclude, we hopefully provided an objective synthesis of what is known, and what is unknown from fragmentation experiments in arthropods. To this end, we searched for all experiments, irrespective of their integration of only patch-scale or landscape-scale processes, and their control for habitat amount. While such information is obviously crucial to better capture the complexity of fragmentation (and is available from our database), we are convinced that among scientists' general interests, one crucial goal is to describe patterns and mechanistically explain them, avoiding judgement on potential beneficial and deleterious effects. It is hazardous to decide, for example, if an increase in species abundance or diversity is beneficial given that any change in ecological networks due to fragmentation can have detrimental consequences for ecosystem functioning as a whole. For instance, an increase in Orthoptera abundance with fragmentation [37] can negatively affect plant biomass [38], with potential cascading effects on belowground species and ecosystem function [39]. It might even occur that these fragmentation-induced changes feedback to habitat fragmentation itself through eco-evolutionary loops [34]. In the future, we hope that long-term experiments will bring elements to feed such questioning and to inform on long-term stability and recovery of anthropized systems.

\section{ACKNOWLEDGEMENTS}

EB was supported by a Young Researchers Award from the Bettencourt-Schueller Foundation. This work was supported by the French Laboratory of Excellence project TULIP (ANR-10-LABX-41), and by an Investissements d'avenir programme from the Agence Nationale de la recherche (no. ANR-11INBS-0001AnaEE-Services). 


\section{REFERENCES}

1. Newbold T, Hudson LN, Hill SLL, Contu S, Lysenko I, Senior RA, Börger L, Bennett DJ, Choimes A, Collen B, et al.: Global effects of land use on local terrestrial biodiversity. Nature 2015, 520:45-50.

**2. Fahrig L: Ecological Responses to Habitat Fragmentation Per Se. Annual Review of Ecology, Evolution, and Systematics 2017, 48:1-23.

A review of empirical studies of significant effects of fragmentation per se show predominance of positive effects, suggesting that deleterious effects of fragmentation is a 'zombie idea'. These results generated an interesting scientific debate (see Fletcher et al 2018 and Fahrig et al 2019 highlighted papers).

**3. Fletcher RJ, Didham RK, Banks-Leite C, Barlow J, Ewers RM, Rosindell J, Holt RD, Gonzalez A, Pardini R, Damschen El, et al.: Is habitat fragmentation good for biodiversity? Biological Conservation 2018, 226:9-15.

The authors question the results of Fahrig's 2017 review. They challenge the methodology used, which focuses on landscape-scale effects, to select the papers. They claim for the consideration of patch-scale effects in fragmented landscapes in addition to landscape-scale effects.

**4. Fahrig L, Arroyo-Rodríguez V, Bennett JR, Boucher-Lalonde V, Cazetta E, Currie DJ, Eigenbrod F, Ford AT, Harrison SP, Jaeger JAG, et al.: Is habitat fragmentation bad for biodiversity? Biological Conservation 2019, 230:179-186.

The authors put emphasis on the difficulty to extrapolate patch-scale mechanisms at the landscape scale. They reiterate their confidence in Fahrig's 2017 review conclusion about positive effects of fragmentation per se.

5. Wilcove DS, McLellan C, Dobson A: Habitat fragmentation in the temperate zone. In Conservation Biology. . 1986:237-256.

6. Fahrig L: Effects of habitat fragmentation on biodiversity. Annu Rev Ecol Evol Syst 2003, 34:487-515.

7. Laurance WF, Lovejoy TE, Vasconcelos HL, Bruna EM, Didham RK, Stouffer PC, Gascon C, Bierregaard RO, Laurance SG, Sampaio E: Ecosystem Decay of Amazonian Forest Fragments: a 22-Year Investigation. Conservation Biology 2002, 16:605-618.

8. Didham RK, Kapos V, Ewers RM: Rethinking the conceptual foundations of habitat fragmentation research. Oikos 2012, 121:161-170.

9. Travis JMJ: Climate change and habitat destruction: a deadly anthropogenic cocktail. Proc $R$ Soc Lond B 2003, 270:467-473.

10. Brook BW, Sodhi NS, Bradshaw CJA: Synergies among extinction drivers under global change. Trends in Ecology \& Evolution 2008, 23:453-460.

11. Mantyka-pringle CS, Martin TG, Rhodes JR: Interactions between climate and habitat loss effects on biodiversity: a systematic review and meta-analysis. Global Change Biology 2012, 18:1239-1252.

12. With KA, Pavuk DM, Worchuck JL, Oates RK, Fisher JL: Threshold effects of landscape structure on biological control in agroecosystems. Ecological Applications 2002, 12:52-65. 
13. Starzomski BM, Srivastava DS: Landscape geometry determines community response to disturbance. Oikos 2007, 116:690-699.

14. Parker M, Mac Nally R: Habitat loss and the habitat fragmentation threshold: an experimental evaluation of impacts on richness and total abundances using grassland invertebrates. Biological Conservation 2002, 105:217-229.

15. Pereira HM, Leadley PW, Proença V, Alkemade R, Scharlemann JPW, Fernandez-Manjarrés JF, Araújo MB, Balvanera P, Biggs R, Cheung WWL, et al.: Scenarios for Global Biodiversity in the 21st Century. Science 2010, 330:1496-1501.

16. Diamond J: Overview: Laboratory Experiments, Field Experiments, and Natural Experiments. In Community Ecology. . 1986.

17. Hurlbert SH: Pseudoreplication and the Design of Ecological Field Experiments. Ecological Monographs 1984, 54:187-211.

18. Scheffers BR, Joppa LN, Pimm SL, Laurance WF: What we know and don't know about Earth's missing biodiversity. Trends in Ecology \& Evolution 2012, 27:501-510.

19. Seastedt TR: The Role of Microarthropods in Decomposition and Mineralization Processes. Annual Review of Entomology 1984, 29:25-46.

20. Caplat P, Edelaar P, Dudaniec RY, Green AJ, Okamura B, Cote J, Ekroos J, Jonsson PR, Löndahl J, Tesson SV, et al.: Looking beyond the mountain: dispersal barriers in a changing world. Front Ecol Environ 2016, 14:261-268.

21. Fardila D, Kelly LT, Moore JL, McCarthy MA: A systematic review reveals changes in where and how we have studied habitat loss and fragmentation over 20years. Biological Conservation 2017, 212:130-138.

22. McGarigal K, Cushman SA: Comparative Evaluation of Experimental Approaches to the Study of Habitat Fragmentation Effects. Ecological Applications 2002, 12:335-345.

23. Shirley MDF, Sibly RM: Metapopulation Dynamics of Fruit Flies Undergoing Evolutionary Change in Patchy Environments. Ecology 2001, 82:3257.

24. Bakker J, van Rijswijk MEC, Weissing FJ, Bijlsma R: Consequences of fragmentation for the ability to adapt to novel environments in experimental Drosophila metapopulations. Conservation Genetics 2010, 11:435-448.

25. LeCraw RM, Srivastava DS, Romero GQ: Metacommunity size influences aquatic community composition in a natural mesocosm landscape. Oikos 2014, 123:903-911.

**26. Resasco J, Bruna EM, Haddad NM, Banks-Leite C, Margules CR: The contribution of theory and experiments to conservation in fragmented landscapes. Ecography 2017, 40:109-118.

Reviewing landscape-scale fragmentation experiments, the authors show some disconnects between typical foci of ecological studies on fragmentation and conservation priorities. They propose avenues to bridge conservation and science.

27. Evans MJ, Banks SC, Driscoll DA, Hicks AJ, Melbourne BA, Davies KF: Short- and long-term effects of habitat fragmentation differ but are predicted by response to the matrix. Ecology 2017, 98:807-819. 
28. Evans MJ, Banks SC, Barton PS, Davies KF, Driscoll DA: A long-term habitat fragmentation experiment leads to morphological change in a species of carabid beetle: Fragmentation changes carabid morphology. Ecological Entomology 2018, 43:282-293.

**29. Haddad NM, Gonzalez A, Brudvig LA, Burt MA, Levey DJ, Damschen El: Experimental evidence does not support the Habitat Amount Hypothesis. Ecography 2017, 40:48-55.

Experimental results refute the Habitat Amount Hypothesis. Not only the total level of habitat in landscape is important, but also the configuration of patches.

30. Haddad NM, Brudvig LA, Clobert J, Davies KF, Gonzalez A, Holt RD, Lovejoy TE, Sexton JO, Austin $\mathrm{MP}$, Collins $C D$, et al.: Habitat fragmentation and its lasting impact on Earth's ecosystems. Science Advances 2015, 1:e1500052.

31. Debinski DM, Holt RD: A Survey and Overview of Habitat Fragmentation Experiments. Conservation Biology 2000, 14:342-355.

32. Legrand D, Guillaume O, Baguette M, Cote J, Trochet A, Calvez O, Zajitschek S, Zajitschek F, Lecomte J, Bénard $Q$, et al.: The Metatron: an experimental system to study dispersal and metaecosystems for terrestrial organisms. Nature Methods 2012, 9:828-833.

33. Haddad NM: Connecting ecology and conservation through experiment. Nat Meth 2012, 9:794-795.

**34. Legrand D, Cote J, Fronhofer EA, Holt RD, Ronce O, Schtickzelle N, Travis JMJ, Clobert J: Ecoevolutionary dynamics in fragmented landscapes. Ecography 2017, 40:9-25.

The consequences of habitat fragmentation on eco-evolutionary dynamics have been intensively studied theoretically, but not experimentally. The authors propose some experimental developments to fill this gap.

35. Prugh LR, Hodges KE, Sinclair ARE, Brashares JS: Effect of habitat area and isolation on fragmented animal populations. PNAS 2008, 105:20770-20775.

36. Baguette M, Blanchet S, Legrand D, Stevens VM, Turlure C: Individual dispersal, landscape connectivity and ecological networks. Biol Rev 2013, 88:310-326.

37. Braschler B, Marini L, Thommen GH, Baur B: Effects of small-scale grassland fragmentation and frequent mowing on population density and species diversity of orthopterans: a long-term study. Ecological Entomology 2009, 34:321-329.

38. Bestion E, Cucherousset J, Teyssier A, Cote J: Non-consumptive effects of a top-predator decrease the strength of the trophic cascade in a four-level terrestrial food web. Oikos 2015, 124:1597-1603.

39. Wardle DA, Bardgett RD, Klironomos JN, Setälä $H$, Putten WH van der, Wall DH: Ecological Linkages Between Aboveground and Belowground Biota. Science 2004, 304:1629-1633. 


\title{
Supplementary Material for
}

\section{Habitat fragmentation experiments on arthropods: what to do next?}

\author{
Elvire Bestion, Julien Cote, Staffan Jacob, Laurane Winandy, Delphine Legrand
}

Current Opinion in Insect Science 2019, 35

Includes:

Supplementary Methods

Figure S1: Flow chart detailing the process of study identification, selection and data extraction

Figure S2: Number of studies focusing on each taxon (A: order, B: family)

Figure S3: Design of the fragmentation studies in terms of secondary measures and eco-evolutionary processes investigated

Figure S4: Number of fragmentation levels, and mean number of landscape replicates per studies Figure S5 Cumulative number of studies over the years investigating several topics of importance Table S1: Identified gaps and suggestions for closing them

References cited in the supplementary material only

Complete list of studies selected for the review 


\section{Supplementary Methods}

We created a data base of existing experiments on habitat fragmentation on arthropods using a systematic review of the literature. From this database, we aimed to provide a full picture of how fragmentation has been manipulated in arthropod experiment by classifying the taxa, the biological level, the fragmentation components manipulated and the response variables, and to identify gaps in the questions addressed and potential shortcomings in experimental approaches. Note that our database was focused on experimental studies, and we did not provide a comparison with nonexperimental studies because we did want to opt for point-scoring between the two valuable experimental and non-experimental approaches. We also did not examine whether fragmentation effects were beneficial or detrimental as it would require a proper meta-analysis and we consider that any change, increase or decrease of a biological metric (e.g. species abundance) can be detrimental at wider ecological scales (see discussion).

We conducted the literature search in two steps: a first step in which we used only the keywords fragmentation AND experiment* (see below), from which we got 2496 results that we then filtered through a two-step exclusion process to get to a set of 159 articles from which we extracted data for our quantitative overview, and a second step in which we used more keywords that we directly derived from the 166 article database, yielding 3369 more articles of which 53 were included. This two search steps procedure allows to avoid forgetting certain types of keywords by searching for keywords that were often present in our initial search and completion of the database. In total, this two-step procedure led to the building of a database of 212 articles. Figure S1 shows the process of study identification, selection and the data extracted from each relevant article.

We first searched Web of Knowledge for the keywords fragmentation AND experiment*, refining for Web of Science Categories biodiversity conservation OR biology OR ecology OR entomology OR environmental sciences $O R$ evolutionary biology $O R$ forestry $O R$ marine freshwater biology $O R$ microbiology OR plant sciences OR soil science OR zoology. The search, undergone in November 2018, revealed 2496 results. We did not include taxonomic information in the search terms to avoid excluding articles where the keywords and abstract did not include taxonomic information, or too specific taxonomic information that would be impossible to search for, but chose to exclude nontaxonomically relevant studies during the first filter. Notice that by focusing on experiment*, we certainly miss studies that were experimental by nature but did not state it explicitly. We used twostep procedure to reduce the 2496 articles to a list of 159 articles fitting our inclusion criteria, first examining the title and abstract, and second examining the full text of the remaining studies and extract information (see below). Examining the full text allowed to identify more keywords that we then used in a second step of search to complete our database. In this step, we focused on studies that would not have fragmentation as a topic but a shorter version of the word (e.g. fragmented), searching for TOPIC: (fragment* AND experiment* NOT fragmentation) Refined by: Web of Science Categories: (Ecology OR Environmental Sciences OR Entomology OR Evolutionary Biology OR Marine freshwater biology OR Plant Sciences or Zoology). Timespan: 1975-2018. We also searched for studies that did not have the fragmentation keyword in the topic but could have keywords linked to one of the fragmentation components that we identified in our first search and analysis of the database, and keywords linked to meta-systems, with the search TOPIC: ((patch number) OR (patch size) OR (edge effect) OR (patch distance) OR (patch isolation) OR (corridor) OR (matrix composition) OR (metapopulation*) OR (metacommunit*) OR (metaecosystem*) OR (meta-population*) OR (meta-communit*) OR (meta-ecosystem*)) AND (experiment*) NOT (fragmentation) Refined by: Web of Science Categories: (Ecology OR Evolutionary Biology. Timespan: 1975-2018. This second step of search yielded 3369 more articles, which were then filtered through our two-step exclusion process in the same way as the articles issued from the first step of search. 
From the list of 2496 original articles, and from the list of 3369 articles from the second search, we examined each title and abstract to determine whether articles met the criteria for inclusion in our overview of the literature. Criteria for inclusion comprised (a) the taxonomic identity of the species or group of species studied, keeping only studies that involved arthropoda, (b) the fact that the study was a manipulative experiment (sensu [17]) by manipulating landscape features, and (c) the fact that the study focused on one or more of the four aspects of habitat fragmentation defined by [6], that is reduction in habitat amount, increase in the number of habitat patches, decrease in the size of habitat patches, and increase in the isolation of habitat patches. We included papers on habitat fragmentation per se (without habitat loss) and papers where the manipulation of fragmentation was linked to a loss of habitat, but not papers that manipulate only habitat loss (exclusion of papers manipulating only patch size). We excluded review papers, purely theoretical papers, and papers that did not fit our definition of experimental, that is a manipulative experiment sensu [17] instead of a mensurative experiment. For instance, we excluded capture-mark-recapture studies that did not explicitly manipulate fragmentation, but only captured individuals present in habitats with various levels of fragmentation, which corresponds more to a mensurative experiment. We also excluded studies that e.g. used pitfall traps to recover insects present in naturally fragmented habitat, if there was no manipulation of the habitat. However, we included all manipulative experiments irrespective of the strength or statistical significance of the results. At times, the title and abstract were too vague to positively assess these three criteria of inclusion, and the articles were kept for further detailed reading of the text; they could be thus excluded in a second filtering session. The first filtering session led to a selection of 345 studies from the original search and 199 studies from the second step of search that fitted the scope of this overview (Fig S1).

The remaining 345 original articles and 199 articles from the second search were then reviewed in full to determine whether they fitted our inclusion criteria, contained relevant data and whether the results were presented with sufficient clarity (Fig S1). This step led to the further exclusion of 186 articles from the first search and 146 articles from the second search. From the final set of 212 studies, we then extracted data relevant to several questions:

1) In which kind of ecological system was fragmentation studied (terrestrial, freshwater, marine)?

2) Which was the biological focus of the study: species level, two- or three-species level including e.g. pollination or predator-prey interactions, community level (small community, $<10$ species, large community, $<100$ species, very large community, $>100$ species), ecosystem level? Which taxa where considered? When studies focused on less than four species, we noted the three species studied. When studies focused on more species, we noted the main taxa studied (e.g. Aphidae and Coccinellidae, maximum three taxa at the lower level to avoid listing each and every taxon in very large communities).

3) Which type of experimental setting was used: artificial habitat in nature/natural landscape, small experimental landscape ( $<1$ ha) large experimental landscape ( $>1$ ha), indoor or outdoor mesocosms $(>1 \mathrm{~m})$, indoor or outdoor microcosms $(<1 \mathrm{~m})$ ? Which kind of experiment was done: landscape manipulation, translocation, dispersal manipulation? Notice that the size of experimental landscapes was arbitrarily divided into small and large based on the 1 ha threshold to simplify analyses, but the scale of habitat fragmentation might depend on the size of the organism studied and the question posed. For instance, $100 \mathrm{~m}^{2}$ is a very large landscape for a mite, but quite small in terms of home range for a dragonfly. Further, studies on dispersal might need very big landscape sizes when focusing for example on dispersal distances, but might be more small-scaled when focusing for example on emigration decision [32,40]. Notice also that while moss systems are correctly considered as natural microcosms, we decided to classify them as artificial habitat in nature/natural 
landscape in our study, at the rare exception of studies enclosing mosses in incubators (classified here as microcosms).

4) Which was the focus of the fragmentation study: e.g. patch number or size, inter-patch distance, patch-source distance, edge effect, corridor, matrix composition? Which other features non-directly related to the fragmentation were studied (e.g. biotic or abiotic patch quality)? As habitat amount is inherently linked with many components of the general fragmentation process (e.g. patch size, patch number), and we did not aim to separate habitat fragmentation per se from more general fragmentation, some components may covary with habitat loss.

5) What was the duration of the study: minutes (up to 59), hours (up to 23), days (up to 6), weeks (up to 3), months (up to 11), years (up to 9), decades? Because extremely few studies reported time in generations, we only report calendar time. However, studies within the same time scale might mean completely different things for long-lived, long generation time species such as cicadas and shortlived, short generation time species like acari.

6) What where the metrics studied: e.g. community structure, population abundance, survival, interspecific interactions, dispersal, phenotypic traits? 
2496 studies identified through database searching: keywords: TOPIC: (fragmentation AND experiment*), Web of Science Categories:

(biodiversity conservation OR biology OR ecology OR entomology OR environmental sciences OR evolutionary biology $O R$ forestry $O R$ marine freshwater biology OR microbiology OR plant sciences OR soil science OR Zoology)

\section{$\downarrow$}

1st filter: 2496 studies with title and abstract screened

2151 studies excluded because irrelevant to study (not focused on arthropods, not experimental or not focusing on fragmentation)

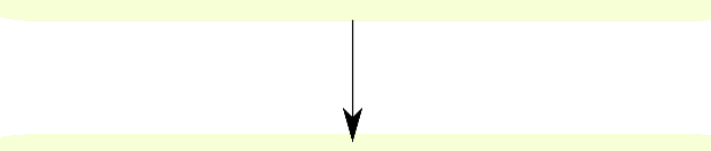

2nd filter: 345 full-text articles assessed for eligibility
186 full-text articles excluded, not fitting eligibility criteria

159 studies included, data extracted for meta analysis: ecological system, biological focus, experimental setting, duration, variables measured

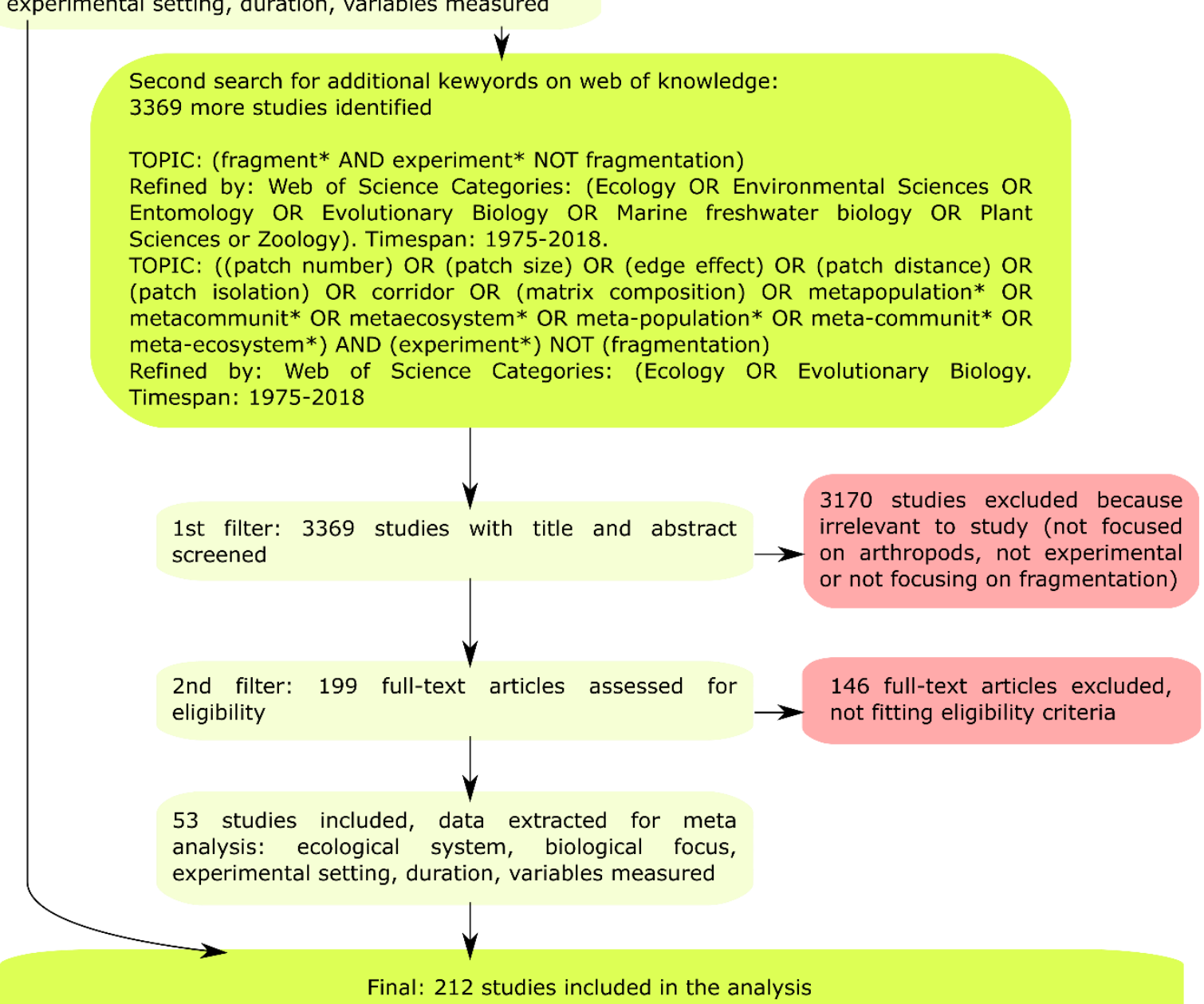

Figure S1: Flow chart detailing the process of study identification, selection and data extraction 


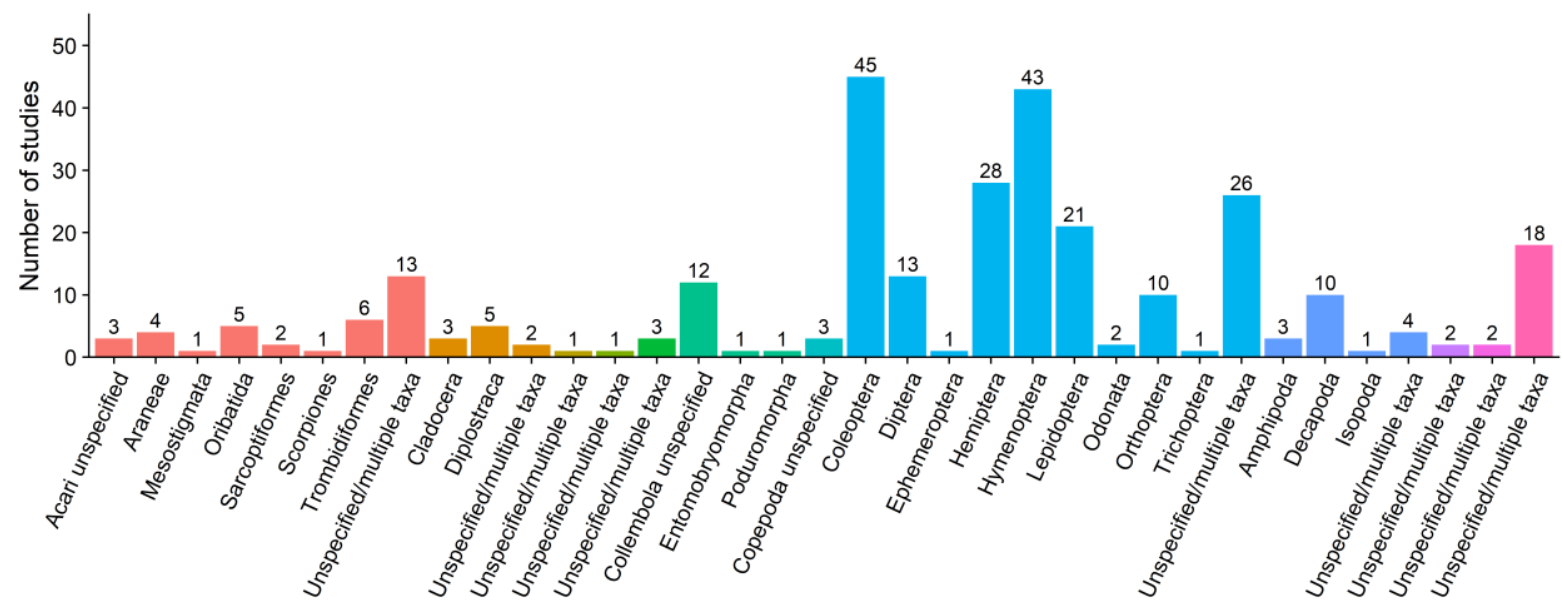

b
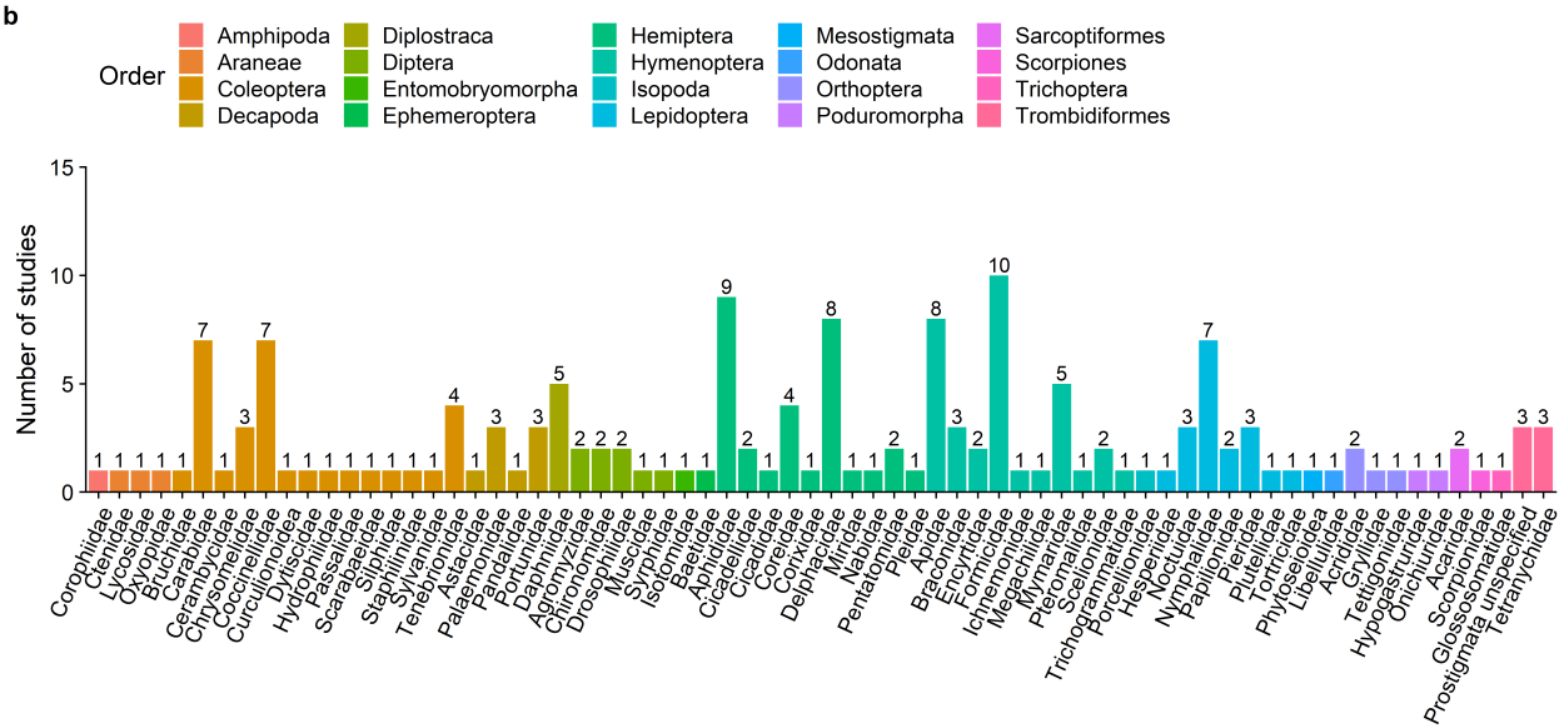

Figure S2: Number of studies focusing on each taxon (a: order, $b$ : family)

Please note that studies that involved more than 3 taxa (resp. order or family) were not taken into account when counting the number of studies using a specific taxon, as it would be complicated to track each and every taxon used in studies on large communities. Also note that the sum of the number of studies investigating each taxon can be superior to the total number of studies as each study can investigate several taxa. 

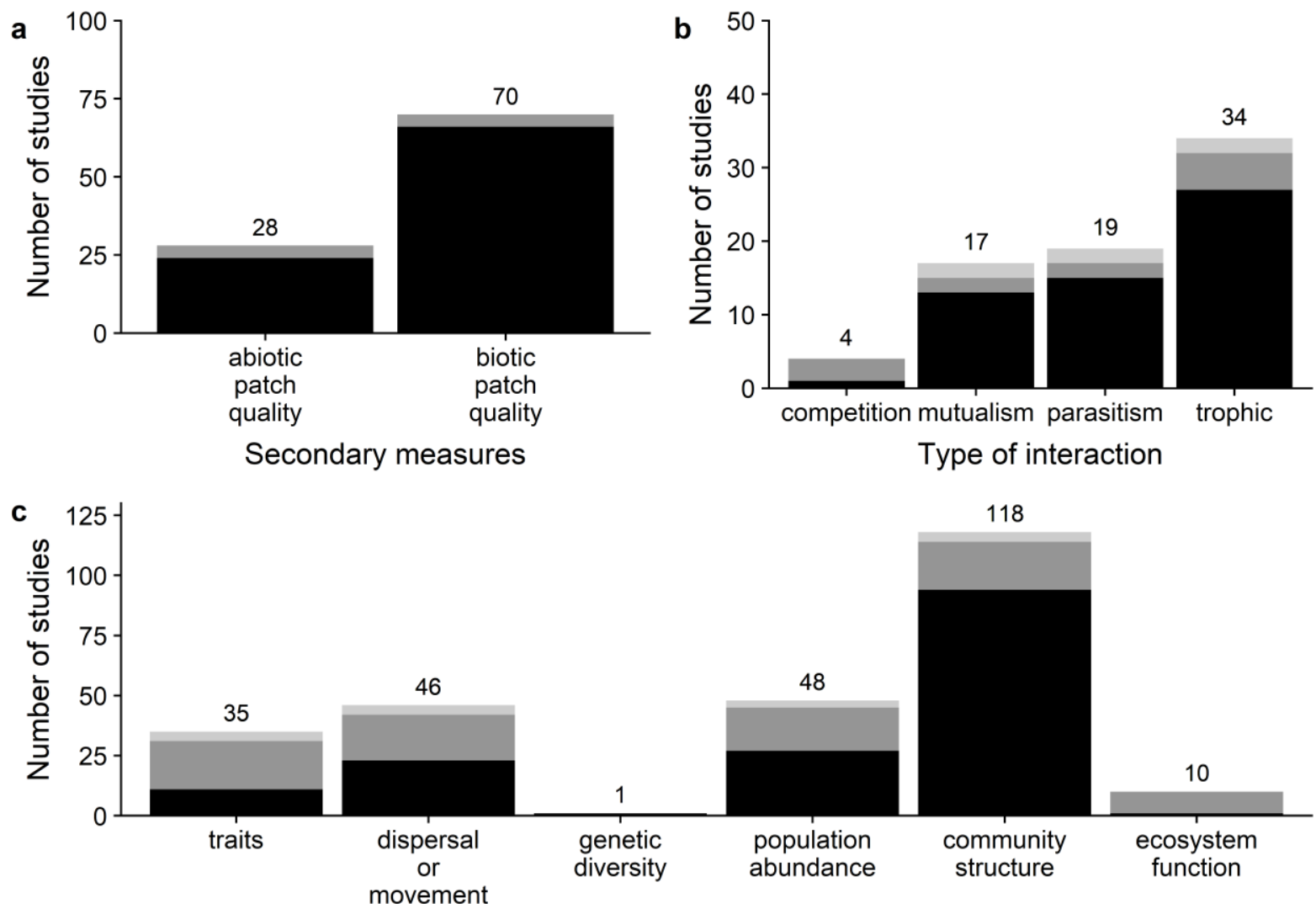

Metrics

Figure S3: Design of the fragmentation studies in terms of secondary measures and eco-evolutionary processes investigated

Note that the total number of studies mapped is superior to the number of studies assessed, as one study can investigate several fragmentation processes and several metrics at once. Black bars: studies that tackled only one measure/feature/metric, grey bars: studies that tackled multiple measures/features/metrics at once (dark grey: 2 measures, light grey: 3 measures) 


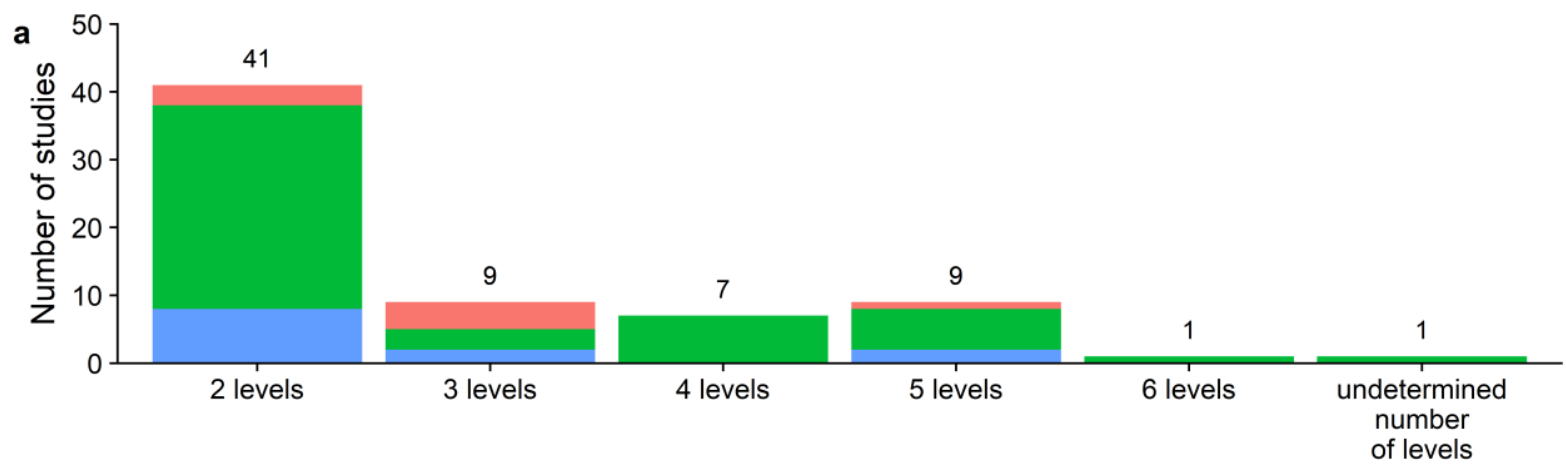

Number of fragmentation levels

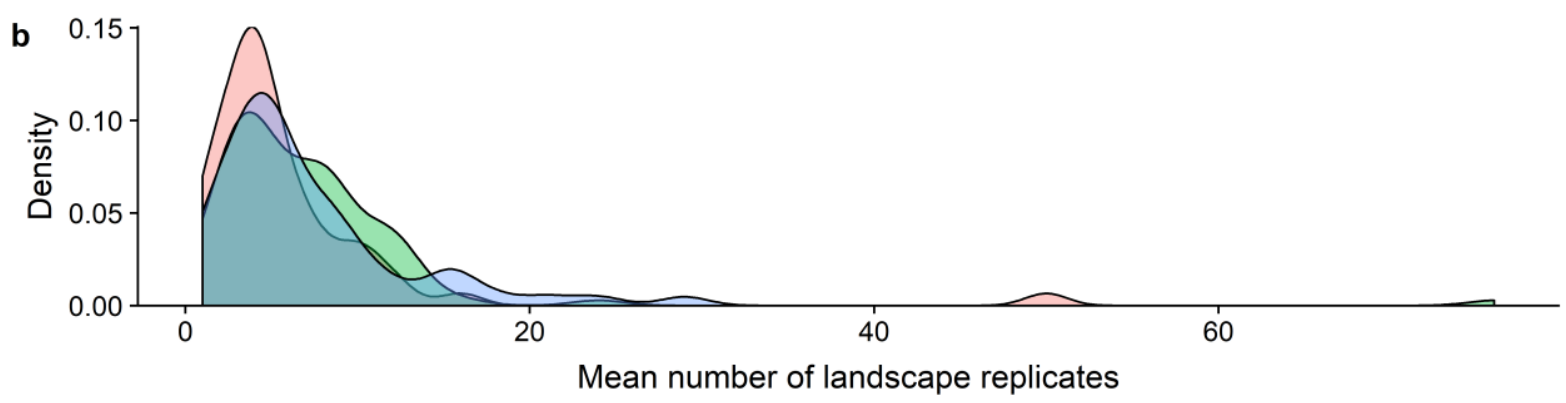

Type of experimental setting $\square$ micro/mesocosm $\square$ experimental landscape $\square \begin{aligned} & \text { artificial habitat in nature/ } \\ & \text { in situ experiment }\end{aligned}$

Figure S4: Number of fragmentation levels, and mean number of landscape replicates per studies

(a) In "continuous vs fragmented" designs, where all components of the fragmentation process vary at the same time, the number of levels of fragmentation used (e.g. continuous/low fragmentation/high fragmentation equals 3 levels). (b) Density plot of the number of landscape replicates per treatment in the studies, separated by type of experimental setting. 


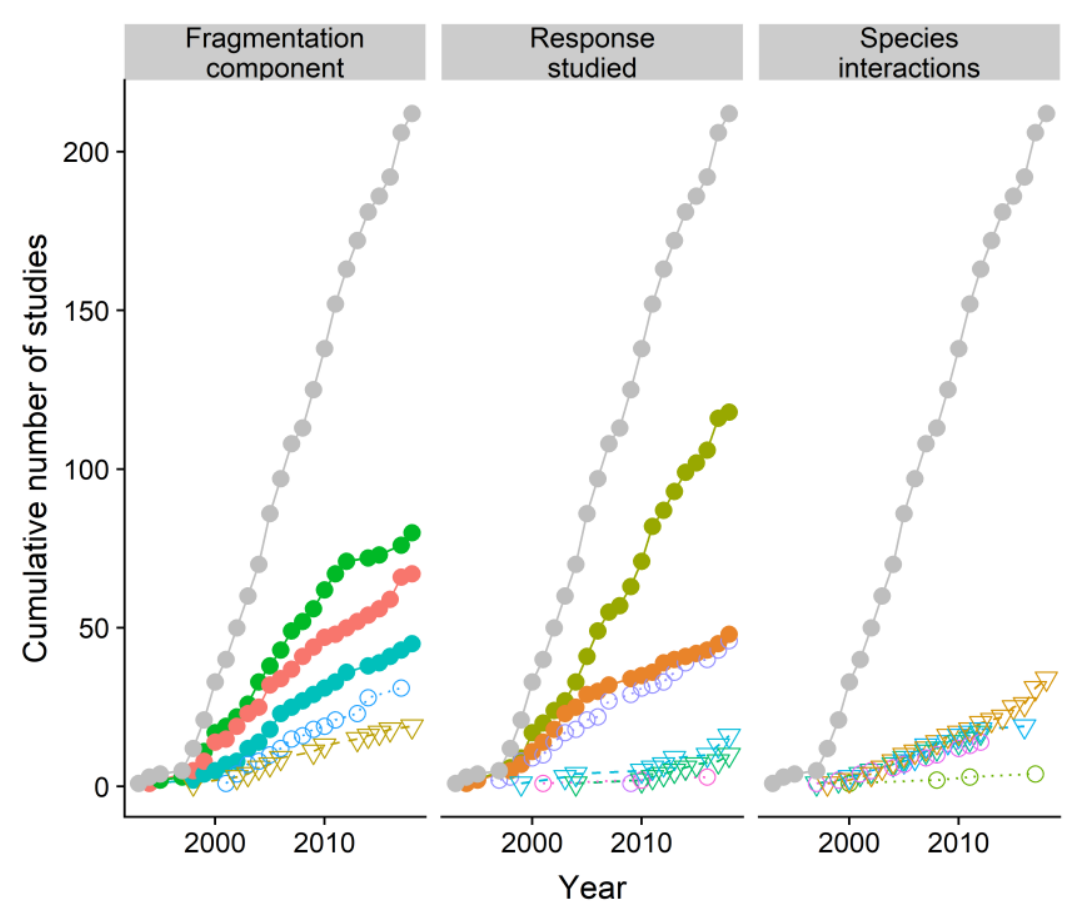

all studies

- patch size

$\forall$ patch number

- patch distance

- edge effect

() matrix composition

- population abundance

- community structure

7 ecosystem function

traits

dispersal or movement

genetic diversity

evolution

$\nabla$ trophic interactions

() competition

$\checkmark$ mutualism

7 parasitism

pollination

Debinski and Holt's (2000) gap

- Not a gap

$\forall$ Our gap

Figure S5 Cumulative number of studies over the years investigating several topics of importance

Dotted lines and empty circles represent the gaps highlighted by Debinski and Holt in 2000 [31], while dashed lines and empty triangles represent gaps highlighted in this review and full lines and filled circles represents topics that are not considered as gaps. 


\section{Table S1: Identified gaps and suggestions for closing them}

(a) identified gaps on the biological focus of the study. (b) Identified gaps on the type of ecological and evolutionary questions addressed. (c) identified gaps in the fragmentation components studied. (d) Other methodological issues.

\begin{tabular}{|c|c|c|}
\hline \multicolumn{3}{|l|}{ (a) Issues of biological focus } \\
\hline Identified Gap & Suggestions & $\begin{array}{l}\text { Example of } \\
\text { study or } \\
\text { conceptual } \\
\text { reference }\end{array}$ \\
\hline $\begin{array}{l}\text { Lack of studies on aquatic } \\
\text { systems }\end{array}$ & $\begin{array}{l}\text { Need for freshwater and marine experimental } \\
\text { platforms. Need for work at the interface } \\
\text { between aquatic and terrestrial realms and how } \\
\text { varying fragmentation between the two realms } \\
\text { affects arthropods persistence }\end{array}$ & {$[25]$} \\
\hline $\begin{array}{l}\text { Studies mainly focused on } \\
\text { certain taxa }\end{array}$ & $\begin{array}{l}\text { Need for studies on lesser studied insects, e.g. } \\
\text { Ephemeroptera, Odonata and Trichoptera which } \\
\text { have complex aquatic/terrestrial life cycles. Need } \\
\text { for investigations in forgotten arthropods like e.g. } \\
\text { Myriapoda, Pycnogonida }\end{array}$ & [41] \\
\hline $\begin{array}{l}\text { Lack of studies on species } \\
\text { interactions and cascading } \\
\text { effects }\end{array}$ & $\begin{array}{l}\text { More approaches in semi-natural systems with } \\
\text { controlled communities can allow to better } \\
\text { understand how e.g. effects of fragmentation on } \\
\text { one species affect other species through } \\
\text { cascading effects }\end{array}$ & [42] \\
\hline $\begin{array}{l}\text { Studies mainly focused on } \\
\text { adults }\end{array}$ & $\begin{array}{l}\text { Need for understanding of effects at different life } \\
\text { stages, particularly for species with complex life } \\
\text { cycles }\end{array}$ & [25] \\
\hline $\begin{array}{l}\text { Lack of studies on model } \\
\text { organisms }\end{array}$ & $\begin{array}{l}\text { Need for building on long-lasting models like } \\
\text { Drosophila species to access mechanistic } \\
\text { understanding of fragmentation effects }\end{array}$ & {$[23,24,43]$} \\
\hline
\end{tabular}




\begin{tabular}{|c|c|c|}
\hline \multicolumn{3}{|c|}{ (b) Issues of eco-evolutionary questions addressed } \\
\hline Identified Gap & Suggestions & $\begin{array}{l}\text { Example of } \\
\text { study or } \\
\text { conceptual } \\
\text { reference }\end{array}$ \\
\hline Lack of ecosystem studies & $\begin{array}{l}\text { Study how arthropod response to fragmentation } \\
\text { affect ecosystem functions (e.g. soil } \\
\text { decomposition, nutrient transfer, ecosystem } \\
\text { respiration) }\end{array}$ & {$[44]$} \\
\hline $\begin{array}{l}\text { Lack of studies on species } \\
\text { interactions }\end{array}$ & $\begin{array}{l}\text { Need for more small community studies where } \\
\text { researchers track the effect of fragmentation on } \\
\text { interaction strength. Particularly, need for studies } \\
\text { on species competition }\end{array}$ & [45] \\
\hline $\begin{array}{l}\text { Lack of studies on } \\
\text { descriptors other than } \\
\text { abundance and community } \\
\text { structure }\end{array}$ & $\begin{array}{l}\text { Studies often focus on species richness while } \\
\text { species respond differently to fragmentation, } \\
\text { need for more studies on species traits as } \\
\text { predictors to sensitivity to fragmentation }\end{array}$ & [46] \\
\hline $\begin{array}{l}\text { Lack of studies on species } \\
\text { traits }\end{array}$ & $\begin{array}{l}\text { Need for studies on phenotypic trade-offs or } \\
\text { syndromes to assess the constraints of trait } \\
\text { response to fragmentation }\end{array}$ & [47] \\
\hline $\begin{array}{l}\text { Lack of studies at the } \\
\text { (epi)genetic level }\end{array}$ & $\begin{array}{l}\text { Need for developing monitoring of (epi)genetic } \\
\text { diversity change in experiments. Need for omics } \\
\text { to unravel the (epi)genetic bases of response to } \\
\text { fragmentation }\end{array}$ & {$[34]$} \\
\hline $\begin{array}{l}\text { Lack of studies on (meta)- } \\
\text { population and community } \\
\text { dynamics (often temporal } \\
\text { snapshots) }\end{array}$ & $\begin{array}{l}\text { Need for temporal monitoring of populations and } \\
\text { communities, ideally with individual monitoring } \\
\text { and information on } \\
\text { survival/reproduction/dispersal rates }\end{array}$ & {$[27,29]$} \\
\hline $\begin{array}{l}\text { No studies on eco- } \\
\text { evolutionary dynamics }\end{array}$ & $\begin{array}{l}\text { Need for experimental designs deciphering the } \\
\text { respective effects of evolutionary processes. } \\
\text { Include common gardens and control without } \\
\text { fragmentation in designs }\end{array}$ & {$[34]$} \\
\hline $\begin{array}{l}\text { Dispersal and movement } \\
\text { often confounded }\end{array}$ & Need for clarification of the processes studied & none \\
\hline
\end{tabular}




\begin{tabular}{|l|l|l|}
\hline \multicolumn{2}{|l|}{ (c) Issues of fragmentation components studied } \\
\hline Identified Gap & Suggestions & $\begin{array}{l}\text { Example } \\
\text { study or } \\
\text { conceptual } \\
\text { reference }\end{array}$ \\
\hline $\begin{array}{l}\text { Lack of studies on matrix } \\
\text { resistance }\end{array}$ & $\begin{array}{l}\text { The quality of the matrix is mainly tackled } \\
\text { through the presence of corridors, need for more } \\
\text { studies on matrix quality gradients }\end{array}$ & {$[27]$} \\
\hline $\begin{array}{l}\text { Lack of studies on patch } \\
\text { number }\end{array}$ & $\begin{array}{l}\text { The mere effect of patch number remains poorly } \\
\text { tackled. Develop designs where patch number } \\
\text { varies independently of habitat amount }\end{array}$ & {$[48]$} \\
\hline $\begin{array}{l}\text { Lack of interactions with } \\
\text { other components of global } \\
\text { change }\end{array}$ & $\begin{array}{l}\text { Need for studies combining e.g. climate change } \\
\text { and pollution with fragmentation }\end{array}$ & {$[23,49]$} \\
\hline $\begin{array}{l}\text { Few levels of habitat } \\
\text { fragmentation }\end{array}$ & $\begin{array}{l}\text { Need for studies with higher number of levels } \\
\text { than just continuous vs fragmented, i.e. } \\
\text { continuous number of fragmentation levels }\end{array}$ & {$[50]$} \\
\hline $\begin{array}{l}\text { Not enough ecological } \\
\text { replication }\end{array}$ & $\begin{array}{l}\text { Need for more replicates at the landscape level in } \\
\text { the design. Need for more biological replicates } \\
\text { when relevant and for more long-term systems in } \\
\text { different biomes }\end{array}$ & {$[30]$} \\
\hline $\begin{array}{l}\text { Not enough long-term } \\
\text { studies }\end{array}$ & $\begin{array}{l}\text { Need for more long-term experiment, and more } \\
\text { time series to have the dynamics of the meta- } \\
\text { populations, -communities, and -ecosystems on } \\
\text { the long term }\end{array}$ & {$[3]$} \\
\hline $\begin{array}{l}\text { Lack of studies on random vs } \\
\text { non-random dispersal }\end{array}$ & $\begin{array}{l}\text { Studies manipulating dispersal as a proxy of } \\
\text { connectivity often do not take into account the } \\
\text { potential for dispersal to be non-random }\end{array}$ & {$[34]$} \\
\hline
\end{tabular}




\begin{tabular}{|c|c|c|}
\hline \multicolumn{3}{|l|}{ (d) Other methodological issues } \\
\hline Identified Gap & Suggestions & $\begin{array}{l}\text { Example of } \\
\text { study or } \\
\text { conceptual } \\
\text { reference }\end{array}$ \\
\hline $\begin{array}{l}\text { Few microcosm/mecocosm } \\
\text { studies }\end{array}$ & $\begin{array}{l}\text { Micro/mesocosms offer more control and } \\
\text { replication particularly for complex eco- } \\
\text { evolutionary designs, relevant for studies } \\
\text { requiring biological reshuffling }\end{array}$ & [51] \\
\hline $\begin{array}{l}\text { Lack of comparability } \\
\text { between study results }\end{array}$ & $\begin{array}{l}\text { - Use effect sizes } \\
\text { - report time in calendar days as well as in } \\
\text { generation time when possible } \\
\text { - use the same protocols to calculate traits linked } \\
\text { to morphology, feeding, life history, physiology or } \\
\text { behaviour } \\
\text { - report numerical abundance as well as density } \\
\text { per } \mathrm{m}^{2}\end{array}$ & {$[52]$} \\
\hline $\begin{array}{l}\text { Not enough information on } \\
\text { taxa }\end{array}$ & $\begin{array}{l}\text { - always specify order and family of the described } \\
\text { species } \\
\text { - follow the ARRIVE guidelines for reporting } \\
\text { studies on animals }\end{array}$ & [53] \\
\hline $\begin{array}{l}\text { Not link with theoretical } \\
\text { models }\end{array}$ & $\begin{array}{l}\text { Build fragmentation experiments to validate } \\
\text { theoretical predictions. Develop mixed } \\
\text { approaches where model can help interpreting } \\
\text { results. Feed existing models with measured } \\
\text { parameters }\end{array}$ & [48] \\
\hline
\end{tabular}




\section{References cited in the supplementary material only}

40. Legrand D, Trochet A, Moulherat S, Calvez O, Stevens VM, Ducatez S, Clobert J, Baguette M: Ranking the ecological causes of dispersal in a butterfly. Ecography 2015, 38:822-831.

41. McCauley SJ, Brodin T, Hammond J: Foraging Rates of Larval Dragonfly Colonists Are Positively Related to Habitat Isolation: Results from a Landscape-Level Experiment. The American Naturalist 2010, 175:E66-E73.

42. Harvey E, MacDougall AS: Trophic island biogeography drives spatial divergence of community establishment. Ecology 2014, 95:2870-2878.

43. Cranmer L, McCollin D, Ollerton J: Landscape structure influences pollinator movements and directly affects plant reproductive success. Oikos 2012, 121:562-568.

44. Staddon P, Lindo Z, Crittenden PD, Gilbert F, Gonzalez A: Connectivity, non-random extinction and ecosystem function in experimental metacommunities. Ecology Letters 2010, 13:543-552.

45. Braschler B, Baur B: Experimental small-scale grassland fragmentation alters competitive interactions among ant species. Oecologia 2005, 143:291-300.

46. Davies KF, Margules CR, Lawrence JF: Which traits of species predict population declines in experimental forest fragments? Ecology 2000, 81:1450-1461.

47. Cote J, Bestion E, Jacob S, Travis J, Legrand D, Baguette M: Evolution of dispersal strategies and dispersal syndromes in fragmented landscapes. Ecography 2017, 40:56-73.

48. Goodwin BJ, Fahrig L: How does landscape structure influence landscape connectivity? Oikos 2002, 99:552-570.

49. Tuff KT, Tuff T, Davies KF: A framework for integrating thermal biology into fragmentation research. Ecol Lett 2016, 19:361-374.

50. Brudvig LA, Leroux SJ, Albert CH, Bruna EM, Davies KF, Ewers RM, Levey DJ, Pardini R, Resasco J: Evaluating conceptual models of landscape change. Ecography 2017, 40:74-84.

51. Gianuca AT, Declerck SAJ, Lemmens P, Meester LD: Effects of dispersal and environmental heterogeneity on the replacement and nestedness components of $\beta$-diversity. Ecology 2017, 98:525-533.

52. Moretti M, Dias ATC, de Bello F, Altermatt F, Chown SL, Azcárate FM, Bell JR, Fournier B, Hedde $M$, Hortal J, et al.: Handbook of protocols for standardized measurement of terrestrial invertebrate functional traits. Funct Ecol 2017, 31:558-567.

53. Kilkenny C, Browne WJ, Cuthill IC, Emerson M, Altman DG: Improving Bioscience Research Reporting: The ARRIVE Guidelines for Reporting Animal Research. PLOS Biology 2010, 8:e1000412. 


\section{Complete list of studies selected for the review}

Abildsnes J, Tommeras Ba: Impacts of experimental habitat fragmentation on ground beetles (Coleoptera, Carabidae) in a boreal spruce forest. Annales Zoologici Fennici 2000

Acevedo Ma, Fletcher Rj: The proximate causes of asymmetric movement across heterogeneous landscapes. Landscape Ecology 2017 doi: 10.1007/s10980-017-0522-y

Amarasekare P: Coexistence of competing parasitoids on a patchily distributed host: Local vs. spatial mechanisms. Ecology 2000 doi: 10.1890/0012-9658(2000)081[1286:COCPOA]2.0.CO;2

Amarasekare P: Spatial dynamics in a host multiparasitoid community. Journal Of Animal Ecology 2000 doi: 10.1046/j.1365-2656.2000.00378.x

Arponen $H$, Bostrom C: Responses of mobile epifauna to small-scale seagrass patchiness: is fragmentation important?. Hydrobiologia 2012 doi: 10.1007/s10750-011-0895-x

Astrom J, Bengtsson J: Patch size matters more than dispersal distance in a mainland-island metacommunity. Oecologia 2011 doi: 10.1007/s00442-011-2024-y

Astrom J,Part T: Negative and matrix-dependent effects of dispersal corridors in an experimental metacommunity. Ecology 2013 doi: 10.1890/11-1795.1

Bakker J, Van Rijswijk Mec, Weissing Fj, Bijlsma R: Consequences of fragmentation for the ability to adapt to novel environments in experimental Drosophila metapopulations. Conservation Genetics 2010 doi: 10.1007/s10592-010-0052-5

Baldissera R, Rodrigues Enl, Hartz Sm: Assessment of the probability of colonization of local spider communities in an experimental landscape. Journal Of Arachnology 2013 doi: 10.1636/P12-50.1

Bancroft Js, Turchin P: An experimental test of fragmentation and loss of habitat with Oryzaephilus surinamensis. Ecology 2003 doi: 10.1890/0012-9658(2003)084[1756:AETOFA]2.0.CO;2

Banks Je: The scale of landscape fragmentation affects herbivore response to vegetation heterogeneity. Oecologia 1998 doi: 10.1007/s004420050654

Banks Je: Differential response of two agroecosystem predators, Pterostichus melanarius (Coleoptera: Carabidae) and Coccinella septempunctata (Coleoptera: Coccinellidae), to habitatcomposition and fragmentation-scale manipulations. Canadian Entomologist 1999 doi: 10.4039/ent131645-5

Banks Je,Gagic V: Aphid parasitoids respond to vegetation heterogeneity but not to fragmentation scale: An experimental field study. Basic And Applied Ecology 2016 doi: 10.1016/j.baae.2016.01.007

Barnes Ad,Emberson Rm,Chapman Hm,Krell Ft,Didham Rk: Matrix habitat restoration alters dung beetle species responses across tropical forest edges. Biological Conservation 2014 doi: 10.1016/j.biocon.2013.12.006 
Barton Ps, Manning Ad, Gibb H, Wood Jt, Lindenmayer Db, Cunningham Sa: Experimental reduction of native vertebrate grazing and addition of logs benefit beetle diversity at multiple scales. Journal Of Applied Ecology 2011 doi: 10.1111/j.1365-2664.2011.01994.x

Berggren $A$, Birath B,Kindvall O: Effect of corridors and habitat edges on dispersal behavior, movement rates, and movement angles in Roesel's bush-cricket (Metrioptera roeseli). Conservation Biology 2001 doi: $10.2307 / 3095412$

Blackburn Hb,Hobbs Nt,Detling Jk: Nonlinear responses to food availability shape effects of habitat fragmentation on consumers. Ecology 2011 doi: 10.2307/29779578

Bowler De, Benton Tg: Variation in dispersal mortality and dispersal propensity among individuals: the effects of age, sex and resource availability. Journal Of Animal Ecology 2009 doi: 10.1111/j.1365-2656.2009.01580.x

Braschler B, Baur B: Effects of experimental small-scale grassland fragmentation on spatial distribution, density, and persistence of ant nests. Ecological Entomology 2003 doi: 10.1111/j.13652311.2003.00549.x

Braschler B, Baur B: Experimental small-scale grassland fragmentation alters competitive interactions among ant species. Oecologia 2005 doi: 10.1007/s00442-004-1778-x

Braschler B, Marini L, Thommen Gh, Baur B: Effects of small-scale grassland fragmentation and frequent mowing on population density and species diversity of orthopterans: a long-term study. Ecological Entomology 2009 doi: 10.1111/j.1365-2311.2008.01080.x

Braschler B,Lampel G,Baur B: Experimental small-scale grassland fragmentation alters aphid population dynamics. Oikos 2003 doi: 10.1034/j.1600-0706.2003.12220.x

Brown $\mathrm{Bl}$, Wahl C, Swan $\mathrm{Cm}$ : Experimentally disentangling the influence of dispersal and habitat filtering on benthic invertebrate community structure. Freshwater Biology 2017 doi: 10.1111/fwb.12995

Bruna Em, Vasconcelos $\mathrm{HI}$, Heredia S: The effect of habitat fragmentation on communities of mutualists: Amazonian ants and their host plants. Biological Conservation 2005 doi: 10.1016/j.biocon.2005.01.026

Bukovinszky T, Potting Rpj, Clough Y, Van Lenteren Jc, Vet Lem: The role of pre- and post-alighting detection mechanisms in the responses to patch size by specialist herbivores. Oikos 2005 doi: 10.1111/j.0030-1299.2005.13707.x

Bull Jc, Pickup Nj, Pickett B, Hassell $\mathrm{Mp}$, Bonsall Mb: Metapopulation extinction risk is increased by environmental stochasticity and assemblage complexity. Proceedings Of The Royal Society BBiological Sciences 2007 doi: 10.1098/rspb.2006.3691

Chase $\mathrm{Jm}$, Bergett $\mathrm{Aa}$, Biro Eg: Habitat isolation moderates the strength of top-down control in experimental pond food webs. Ecology 2010 doi: 10.1890/09-0262.1

Chisholm C, Lindo Z, Gonzalez A: Metacommunity diversity depends on connectivity and patch arrangement in heterogeneous habitat networks. Ecography 2011 doi: 10.1111/j.16000587.2010.06588.x 
Collinge Sk: Effects of grassland fragmentation on insect species loss, colonization, and movement patterns. Ecology 2000 doi: 10.1890/0012-9658(2000)081[2211:EOGFOI]2.0.CO;2

Collinge Sk, Forman Rtt: A conceptual model of land conversion processes: predictions and evidence from a microlandscape experiment with grassland insects. Oikos 1998 doi: $10.2307 / 3546918$

Collinge Sk, Palmer Tm: The influences of patch shape and boundary contrast on insect response to fragmentation in California grasslands. Landscape Ecology 2002 doi: 10.1023/A:1021536302195

Collinge Sk: Spatial arrangement of habitat patches and corridors: clues from ecological field experiments. Landscape And Urban Planning 1998 doi: 10.1016/s0169-2046(98)00085-1

Cook Wm, Holt $\mathrm{Rd}$ : Influence of multiple factors on insect colonization of heterogeneous landscapes: A review and case study with periodical cicadas (Homoptera: Cicadidae). Annals Of The Entomological Society Of America 2006 doi: 10.1603/0013-8746(2006)99[809:IOMFOI]2.0.CO;2

Cranmer L, Mccollin D, Ollerton J: Landscape structure influences pollinator movements and directly affects plant reproductive success. Oikos 2012 doi: 10.1111/j.1600-0706.2011.19704.x

Creighton J, Bastarache R, Lomolino M, Belk M: Effect of forest removal on the abundance of the endangered American burying beetle, Nicrophorus americanus (Coleoptera: Silphidae). Journal Of Insect Conservation 2009 doi: 10.1007/s10841-007-9115-4

Cresswell Je: Spatial heterogeneity, pollinator behaviour and pollinator-mediated gene flow: Bumblebee movements in variously aggregated rows of oil-seed rape. Oikos 1997 doi: $10.2307 / 3545616$

Crist To, Pradhan-Devare Sv, Summerville Ks: Spatial variation in insect community and species responses to habitat loss and plant community composition. Oecologia 2006 doi: 10.1007/s00442005-0275-1

Cronin Jt: Matrix heterogeneity and host-parasitoid interactions in space. Ecology 2003 doi: 10.1890/0012-9658(2003)084[1506:MHAHII]2.0.CO;2

Cronin Jt: Patch structure, oviposition behaviour, and the distribution of parasitism risk. Ecological Monographs 2003 doi: 10.1890/0012-9615(2003)073[0283:PSOBAT]2.0.CO;2

Cronin Jt: From population sources to sieves: the matrix alters host-parasitoid source-sink structure. Ecology 2007 doi: 10.1890/07-0070.1

Cronin Jt: Habitat edges, within-patch dispersion of hosts, and parasitoid oviposition behavior. Ecology 2009 doi: 10.1890/08-0208.1

Darcy Mc, Eggleston Db: Do habitat corridors influence animal dispersal and colonization in estuarine systems?. Landscape Ecology 2005 doi: 10.1007/s10980-005-3704-y

Davies Kf, Margules $\mathrm{Cr}$ : Effects of habitat fragmentation on carabid beetles: experimental evidence. Journal Of Animal Ecology 1998 doi: 10.1046/j.1365-2656.1998.00210.x 
Davies Kf, Margules $\mathrm{Cr}$, Lawrence Jf: A synergistic effect puts rare, specialized species at greater risk of extinction. Ecology 2004 doi: 10.1890/03-0110

Davies $\mathrm{Kf}$, Margules $\mathrm{Cr}$, Lawrence $\mathrm{Kf}$ : Which traits of species predict population declines in experimental forest fragments?. Ecology 2000 doi: 10.1890/00129658(2000)081[1450:WTOSPP]2.0.CO;2

Davies Kf, Melbourne $\mathrm{Ba}$, Margules $\mathrm{Cr}$ : Effects of within- and between patch processes on community dynamics in a fragmentation experiment. Ecology 2001 doi: 10.1890/00129658(2001)082[1830:EOWABP]2.0.CO;2

De Roissart A, Wang Sp, Bonte D: Spatial and spatiotemporal variation in metapopulation structure affects population dynamics in a passively dispersing arthropod. Journal of Animal Ecology 2015 doi: 10.1111/1365-2656.12400

De Roissart A, Wybouw N, Renault D, Van Leeuwen T, Bonte D: Life-history evolution in response to changes in metapopulation structure in an arthropod herbivore. Functional Ecology 2016 doi: 10.1111/1365-2435.12612

Deans Am, Malcolm Jr, Smith Sm, Bellocq Mi: Edge effects and the responses of aerial insect assemblages to structural-retention harvesting in Canadian boreal peatland forests. Forest Ecology And Management 2005 doi: 10.1016/j.foreco.2004.09.015

Deans Ra, Chalcraft Dr: Matrix context and patch quality jointly determine diversity in a landscape-scale experiment. Oikos 2017 doi: 10.1111/oik.03809

Denys C,Tscharntke T: Plant-insect communities and predator-prey ratios in field margin strips, adjacent crop fields, and fallows. Oecologia 2002 doi: 10.1007/s004420100796

Dgebuadze Py, Mehova Es, Britayev Ta: Recolonization of the Himerometra robustipinna (Himerometridae, Crinoidea) by macrosymbionts: an in situ experiment. Symbiosis 2012 doi: 10.1007/s13199-013-0227-1

Didham Rk, Lawton Jh, Hammond Pm, Eggleton P: Trophic structure stability and extinction dynamics of beetles (Coleoptera) in tropical forest fragments. Philosophical Transactions of The Royal Society B-Biological Sciences 1998 doi: 10.1098/rstb.1998.0221

Diekotter T,Haynes Kj,Mazeffa D,Crist To: Direct and indirect effects of habitat area and matrix composition on species interactions among flower-visiting insects. Oikos 2007 doi: $10.2307 / 40235209$

Downing Al, Brown Bl, Leibold Ma: Multiple diversity-stability mechanisms enhance population and community stability in aquatic food webs. Ecology 2014 doi: 10.1890/12-1406.1

Drake Jm, Griffen Bd: Experimental demonstration of accelerated extinction in source-sink metapopulations. Ecology And Evolution 2013 doi: 10.1002/ece3.713

Duncan Dh, Nicotra Ab, Wood Jt, Cunningham Sa: Plant isolation reduces outcross pollen receipt in a partially self-compatible herb. Journal Of Ecology 2004 doi: 10.1111/j.1365-2745.2004.00933.x 
Eggleston $\mathrm{Db}$, Elis We, Etherington Ll, Dahlgren $\mathrm{Cp}$, Posey Mh: Organism responses to habitat fragmentation and diversity: Habitat colonization by estuarine macrofauna. Journal of Experimental Marine Biology And Ecology 1999 doi: 10.1016/S0022-0981(98)00192-0

Eggleston $\mathrm{Db}$,Etherington LI,Elis We: Organism response to habitat patchiness: species and habitatdependent recruitment of decapod crustaceans. Journal Of Experimental Marine Biology And Ecology 1998 doi: 10.1016/s0022-0981(97)00154-8

Elzinga Ja, Turin $\mathrm{H}$, Van Damme Jmm, Biere A: Plant population size and isolation affect herbivory of Silene latifolia by the specialist herbivore Hadena bicruris and parasitism of the herbivore by parasitoids. Oecologia 2005 doi: 10.1007/s00442-005-0096-2

Elzinga Ja, Van Nouhuys S, Van Leeuwen D-J, Biere A: Distribution and colonisation ability of three parasitoids and their herbivorous host in a fragmented landscape . Basic And Applied Ecology 2007 doi: 10.1016/j.baae.2006.04.003

Esch S, Klinkhamer Pgl, Van Der Meijden E: Do distances among host patches and host density affect the distribution of a specialist parasitoid?. Oecologia 2005 doi: 10.1007/s00442-005-0214-1

Evans Dm, Turley Ne, Levey $\mathrm{Dj}$, Tewksbury Jj: Habitat patch shape, not corridors, determines herbivory and fruit production of an annual plant. Ecology 2012 doi: 10.1890/11-0642.1

Evans Mj, Banks Sc, Barton Ps, Davies Kf, Driscoll Da: A long-term habitat fragmentation experiment leads to morphological change in a species of carabid beetle. Ecological Entomology 2018 doi: $10.1111 /$ een.12498

Evans Mj,Banks Sc,Driscoll Da,Hicks Aj,Melbourne Ba,Davies Kf: Short- and long--term effects of habitat fragmentation differ but are predicted by response to the matrix. Ecology 2016 doi: 10.1002/ecy.1704

Ewers Rm: Spatio-temporal variation in mortality rates of Mecodema spp. (Coleoptera: Carabidae) across a forest-grassland edge in New Zealand. Insect Conservation And Diversity 2008 doi: 10.1111/j.1752-4598.2007.00006.x

Fenoglio Ms, Salvo A, Videla M, Valladares Gr: Plant patch structure modifies parasitoid assemblage richness of a specialist herbivore. Ecological Entomology 2010 doi: 10.1111/j.13652311.2010.01218.x

Ferguson Sh: Influence of edge on predator-prey distribution and abundance. Acta OecologicaInternational Journal Of Ecology 2004 doi: 10.1016/j.actao.2003.12.001

Fletcher Rj,Acevedo Ma,Robertson Ep: The matrix alters the role of path redundancy on patch colonization rates. Ecology 2014 doi: 10.1890/13-1815.1

Foord Sh, Ferguson Jwh, Van Jaarsveld As: Coleopteran assemblages in afromontane grasslands reflect fine-scale variation in vegetation. Environmental Entomology 2003 doi: 10.1603/0046-225X32.4.797

Forbes Ae,Chase Jn: The role of habitat connectivity and landscape geometry in experimental zooplankton metacommunities. Oikos 2002 doi: 10.1034/j.1600-0706.2002.960305.x 
Fried Jh, Levey $\mathrm{Dj}$, Hogsette Ja: Habitat corridors function as both drift fences and movement conduits for dispersing flies. Oecologia 2005 doi: 10.1007/s00442-005-0023-6

Genua L,Start D,Gilbert B: Fragment size affects plant herbivory via predator loss. Oikos 2017 doi: 10.1111/oik.04223

Gianuca At, Declerck Saj, Lemmens P, De Meester L: Effects of dispersal and environmental heterogeneity on the replacement and nestedness components of beta-diversity. Ecology 2017 doi: 10.1002/ecy.1666

Gilbert F, Gonzalez A, Evans-Freke I: Corridors maintain species richness in the fragmented landscapes of a microecosystem. Proceedings Of The Royal Society B-Biological Sciences 1998 doi: 10.1098/rspb.1998.0333

Godbold Ja, Bulling Mt, Solan M: Habitat structure mediates biodiversity effects on ecosystem properties. Proceedings Of The Royal Society B-Biological Sciences 2011 doi: 10.1098/rspb.2010.2414

Golden Dm, Crist To: Experimental effects of habitat fragmentation on old-field canopy insects: community, guild and species responses. Oecologia 1999 doi: 10.1007/s004420050738

Golden Dm, Crist To: Experimental effects of habitat fragmentation on rove beetles and ants: patch area or edge?. Oikos 2000 doi: 10.1034/j.1600-0706.2000.900311.x

Gonzalez A: Community relaxation in fragmented landscapes: the relation between species richness, area and age. Ecology Letters 2000 doi: 10.1046/j.1461-0248.2000.00171.x

Gonzalez A,Chaneton Ej: Heterotroph species extinction, abundance and biomass dynamics in an experimentally fragmented microecosystem. Journal Of Animal Ecology 2002 doi: 10.1046/j.13652656.2002.00625.x

Goodwin Bj, Fahrig L: How does landscape structure influence landscape connectivity?. Oikos 2002 doi: 10.1034/j.1600-0706.2002.11824.x

Goverde M, Schweizer K, Baur B, Erhardt A: Small-scale habitat fragmentation effects on pollinator behaviour: experimental evidence from the bumblebee Bombus veteranus on calcareous grasslands. Biological Conservation 2002 doi: 10.1016/S0006-3207(01)00194-X

Grainger Tn, Gilbert B: Multi-scale responses to warming in an experimental insect metacommunity. Global Change Biology 2017 doi: 10.1111/gcb.13777

Grez A, Zaviezo T, Tischendorf L, Fahrig L: A transient, positive effect of habitat fragmentation on insect population densities. Oecologia 2004 doi: 10.1007/s00442-004-1670-8

Grez Aa, Zaviezo T, Diaz S, Camousseigt B, Cortes G: Effects of habitat loss and fragmentation on the abundance and species richness of aphidophagous beetles and aphids in experimental alfalfa landscapes. European Journal Of Entomology 2008 doi: 10.14411/eje.2008.052

Grez Aa, Zaviezo T, Reyes S: Short-term effects of habitat fragmentation on the abundance and species richness of beetles in experimental alfalfa microlandscapes. Revista Chilena De Historia Natural 2004 
Grez Aa, Zaviezo T, Rios M: Ladybird (Coleoptera: Coccinellidae) dispersal in experimental fragmented alfalfa landscapes. European Journal Of Entomology 2005 doi: 10.14411/eje.2005.033

Griffen $B d$, Drake Jm: Environment, but not migration rate, influences extinction risk in experimental metapopulations. Proceedings Of The Royal Society B-Biological Sciences 2009 doi: doi:10.1098/rspb.2009.1153

Grosholz Ed: The influence of habitat heterogeneity on host-pathogen population dynamics. Oecologia 1993 doi: 10.1007/BF00317504

Haddad Nm: Corridor and distance effects on interpatch movements: a landscape experiment with butterflies. Ecological Applications 1999 doi: 10.1890/1051-0761(1999)009[0612:CADEOI]2.0.CO;2

Haddad Nm,Baum Ka: An experimental test of corridor effects on butterfly densities. Ecological Applications 1999 doi: 10.2307/2641149

Haddad Nm,Bowne Dr,Cunningham A,Danielson Bj,Levey Dj,Sargent S,Spira T: Corridor use by diverse taxa. Ecology 2003 doi: 10.1890/0012-9658(2003)084[0609:CUBDT]2.0.CO;2

Haddad Nm,Gonzalez A,Brudvig La,Burt Ma,Levey Dj,Damschen Ei: Experimental evidence does not support the Habitat Amount Hypothesis. Ecography 2016 doi: 10.1111/ecog.02535

Haddad Nm,Tewksbury Jj: Low-quality habitat corridors as movement conduits for two butterfly species. Ecological Applications 2005 doi: 10.1890/03-5327

Hahn Pg, Orrock Jl: Spatial arrangement of canopy structure and land-use history alter the effect that herbivores have on plant growth. Ecosphere 2015 doi: 10.1890/ES15-00036.1

Harrison S, Thomas Cd, Lewinsohn Tm: Testing a metapopulation model of coexistence in the insect community on ragwort (Senecio jacobaea). The American Naturalist 1995 doi: $10.1086 / 285755$

Harvey $E$, Macdougall As: Trophic island biogeography drives spatial divergence of community establishment. Ecology 2014 doi: 10.1890/13-1683.1

Harvey E, Macdougall As: Spatially Heterogeneous Perturbations Homogenize the Regulation of Insect Herbivores. American Naturalist 2015 doi: 10.1086/683199

Harvey E, Macdougall As: Habitat Loss and Herbivore Attack in Recruiting Oaks. American Midland Naturalist 2015 doi: 10.1674/amid-173-02-218-228.1

Harwell Hd, Posey Mh, Alphin Td: Landscape aspects of oyster reefs: Effects of fragmentation on habitat utilization. Journal Of Experimental Marine Biology And Ecology 2011 doi: 10.1016/j.jembe.2011.07.036

Hawn $\mathrm{Cl}$,Herrmann Jd,Griffin $\mathrm{Sr}$,Haddad Nm: Connectivity increases trophic subsidies in fragmented landscapes. Ecology Letters 2018 doi: 10.1111/ele.12958

Haynes $\mathrm{Kj}$, Cronin Jt: Matrix composition affects the spatial ecology of a prairie planthopper. Ecology 2003 doi: 10.1890/02-0611 
Haynes $\mathrm{Kj}$, Cronin Jt: Interpatch movement and edge effects: the role of behavioral responses to the landscape matrix. Oikos 2006 doi: 10.1111/j.0030-1299.2006.13977.x

Haynes $\mathrm{Kj}$, Diekotter T, Crist To: Resource complementation and the response of an insect herbivore to habitat area and fragmentation. Oecologia 2007 doi: 10.1007/s00442-007-0749-4

Haynes Kk, Dillemuth Fp, Anderson Bj, Hakes As, Jackson Hb, Jackson Se, Cronin Jt: Landscape context outweighs local habitat quality in its effects on herbivore dispersal and distribution. Oecologia 2007 doi: 10.1007/s00442-006-0600-3

Haynes $\mathrm{Kj}$,Crist To: Insect herbivory in an experimental agroecosystem: the relative importance of habitat area, fragmentation, and the matrix. Oikos 2009 doi: 10.1111/j.1600-0706.2009.17720.x

Hein Am, Gillooly Jf: Predators, prey, and transient states in the assembly of spatially structured communities. Ecology 2011 doi: 10.1890/10-1922.1

Herrmann Jd, Haddad Nm, Levey $\mathrm{Dj}$ : Testing the relative importance of local resources and landscape connectivity on Bombus impatiens (Hymenoptera, Apidae) colonies. Apidologie 2017 doi: 10.1007/s13592-017-0499-1

Hovel Ka,Fonseca Ms: Influence of seagrass landscape structure on the juvenile blue crab habitatsurvival function. Marine Ecology Progress Series 2005 doi: 10.3354/meps300179

Howeth Jg: Native species dispersal reduces community invasibility by increasing species richness and biotic resistance. Journal Of Animal Ecology 2017 doi: 10.1111/1365-2656.12733

Howeth Jg, Leibold Ma: Prey dispersal rate affects prey species composition and trait diversity in response to multiple predators in metacommunities. Journal Of Animal Ecology 2010 doi: 10.1111/j.1365-2656.2010.01715.x

Hoyle M: Experimentally fragmented communities are more aggregated. Journal Of Animal Ecology 2005 doi: $10.1111 /$ j.1365-2656.2005.00938.x

Hoyle M,Gilbert F: Species richness of moss landscapes unaffected by short-term fragmentation. Oikos 2004 doi: $10.2307 / 3548096$

Ims Ra, Leinaas $\mathrm{Hp}$, Coulson S: Spatial and temporal variation in patch occupancy and population density in a model system of an arctic Collembola species assemblage. Oikos 2004 doi: 10.1111/j.0030-1299.2004.12634.x

Ishihama F, Washitani I: Behavior of queen bumblebee pollinators on Primula sieboldii (Primulaceae) in response to different patch sizes and spacing. Plant Species Biology 2007 doi: 10.1111/j.1442-1984.2007.00189.x

Jackson $\mathrm{Hb}$, Zeccarias $\mathrm{A}$, Cronin Jt: Mechanisms driving the density-area relationship in a saproxylic beetle. Oecologia 2013 doi: 10.1007/s00442-013-2697-5

Johnson Jb, Hagen Rh, Martinko Ea: Effect of Succession and Habitat Area on Wandering Spider (Araneae) Abundance in an Experimental Landscape. Journal Of The Kansas Entomological Society 2010 doi: $10.2317 / J K E S 0707.06 .1$ 
Kishbough $\mathrm{Ma}$, Yocom Dh: The impact of habitat fragmentation on arthropod biodiversity - An experimental study. American Biology Teacher 2000 doi: 10.1662/00027685(2000)062[0414:TIOHFO]2.0.CO;2

Klapwijk Mj, Lewis Ot: Host-parasitoid dynamics in a fragmented landscape: Holly trees, holly leaf miners and their parasitoids. Basic And Applied Ecology 2012 doi: 10.1016/j.baae.2011.12.002

Kobayashi T, Kitahara M, Tanaka E: Effects of habitat fragmentation on the three-way interaction among ants, aphids and larvae of the giant purple emperor, Sasakia charonda (Hewitson), a nearthreatened butterfly. Ecological Research 2008 doi: 10.1007/s11284-007-0400-1

Kolb A: Habitat fragmentation reduces plant fitness by disturbing pollination and modifying response to herbivory. Biological Conservation 2008 doi: 10.1016/j.biocon.2008.07.015

Kross Sm, Kelsey Tr, Mccoll $\mathrm{Cj}$, Townsend Jm: Field-scale habitat complexity enhances avian conservation and avian-mediated pest-control services in an intensive agricultural crop. Agriculture Ecosystems \& Environment 2016 doi: 10.1016/j.agee.2016.03.043

Kruess A,Tscharntke T: Species richness and parasitism in a fragmented landscape: experiments and field studies with insects on Vicia sepium. Oecologia 2000 doi: 10.1007/PL00008829

Lecraw Rm, Srivastava Ds, Romero Gq: Metacommunity size influences aquatic community composition in a natural mesocosm landscape. Oikos 2014 doi: 10.1111/oik.01253

Ledergerber S, Dolt C, Zschokke S, Baur B: Effects of experimental small-scale grassland fragmentation on the extent of grazing damage in Trifolium repens seedlings. Acta OecologicaInternational Journal Of Ecology 2002 doi: 10.1016/S1146-609X(02)01162-1

Lin Wt, Pennings Sc: Predator-prey interactions in a ladybeetle-aphid system depend on spatial scale. Ecology And Evolution 2018 doi: 10.1002/ece3.4117

Lindo Z, Whiteley J, Gonzalez A: Traits explain community disassembly and trophic contraction following experimental environmental change. Global Change Biology 2012 doi: 10.1111/j.13652486.2012.02725.x

Littlewood N, Pakeman R, Woodin S: Isolation of habitat patches limits colonisation by moorland Hemiptera. Journal Of Insect Conservation 2009 doi: 10.1007/s10841-007-9114-5

Ljungberg $\mathrm{P}$, Hasper Tb, Nilsson $\mathrm{Pa}$, Persson A: Effects of small-scale habitat fragmentation on predator-prey interactions in a temperate sea grass system. Marine Biology 2013 doi: 10.1007/s00227-012-2122-3

Louca V, Ream Hm, Findlay Jd, Latham D, Lucas Mc: Do culverts impact the movements of the endangered white-clawed crayfish?. Knowledge And Management Of Aquatic Ecosystems 2014 doi: $10.1051 / \mathrm{kmae} / 2014029$

Luque Gm, Lopez Jr: Effect of experimental small-scale spatial heterogeneity on resource use of a Mediterranean ground-ant community. Acta Oecologica-International Journal Of Ecology 2007 doi: 10.1016/j.actao.2007.03.003 
Macreadie $\mathrm{Pi}$, Geraldi $\mathrm{Nr}$, Peterson $\mathrm{Ch}$ : Preference for feeding at habitat edges declines among juvenile blue crabs as oyster reef patchiness increases and predation risk grows. Marine Ecology Progress Series 2012 doi: 10.3354/meps09986

Macreadie Pi,Connolly Rm,Keough Mj,Jenkins Gp,Hindell Js: Short-term differences in animal assemblages in patches formed by loss and growth of habitat. Austral Ecology 2009 doi: 10.1111/j.1442-9993.2009.02060.x

Margules $\mathrm{Cr}$, Milkovits $\mathrm{Ga}$, Smith Gt: CONTRASTING EFFECTS OF HABITAT FRAGMENTATION ON THE SCORPION CERCOPHONIUS-SQUAMA AND AN AMPHIPOD. Ecology 1994 doi: 10.2307/1941608

Marshall Sd, Walker Se, Rypstra Al: Two ecologically-divergent generalist predators have different responses to landscape fragmentation. Oikos 2006 doi: 10.1111/j.2006.0030-1299.14115.x

Martinko Ea, Hagen Rh, Griffith Ja: Successional change in the insect community of a fragmented landscape. Landscape Ecology 2006 doi: 10.1007/s10980-005-5322-0

Martins Gm, Matias Mg, Moniz I, Rius C, Sanderson J, Neto Ai, Jenkins Sr: Post-settlement dispersal ability determines structure of marine benthic metacommunities. Marine Ecology Progress Series 2017 doi: 10.3354/meps12108

Matias Mg: Macrofaunal responses to structural complexity are mediated by environmental variability and surrounding habitats. Marine Biology 2013 doi: 10.1007/s00227-012-2155-7

Mccauley E, Kendall Be, Janssen A, Wood S, Murdoch Ww, Hosseini P, Briggs Cj, Ellner Sp, Nisbet $\mathrm{Rm}$, Sabelis $\mathrm{Mw}$, Turchin $\mathrm{P}$ : Inferring colonization processes from population dynamics in spatially structured predator-prey systems. Ecology 2000 doi: 10.1890/00129658(2000)081[3350:ICPFPD]2.0.CO;2

Mccauley $\mathrm{Sj}$, Brodin $\mathrm{T}$, Hammond $\mathrm{J}$ : Foraging rates of larval dragonfly colonists are positively related to habitat isolation: results from a landscape-level experiment. The American Naturalist 2010 doi: $10.1086 / 650444$

Mcintyre Ne, Wiens Ja: How does habitat patch size affect animal movement? An experiment with darkling beetles. Ecology 1999 doi: 10.1890/0012-9658(1999)080[2261:HDHPSA]2.0.CO;2

Mcintyre Ne, Wiens Ja: Interactions between habitat abundance and configuration: experimental validation of some predictions from percolation theory. Oikos 1999 doi: 10.2307/3546577

Mestre L, Jansson $\mathrm{N}$, Ranius $\mathrm{T}$ : Saproxylic biodiversity and decomposition rate decrease with small-scale isolation of tree hollows. Biological Conservation 2018 doi: 10.1016/j.biocon.2018.09.023

Minello Tj, Zimmerman Rj, Medina R: The importance of edge for natant macrofauna in a created salt marsh. Wetlands 1994 doi: 10.1007/BF03160655

Moore Ec,Hovel Ka: Relative influence of habitat complexity and proximity to patch edges on seagrass epifaunal communities. Oikos 2010 doi: 10.1111/j.1600-0706.2009.17909.x

Morel-Journel T, Hautier M, Vercken E, Mailleret L: Clustered or scattered? The impact of habitat quality clustering on establishment and early spread. Ecography 2018 doi: 10.1111/ecog.03397 
Olden Jd: Critical threshold effects of benthiscape structure on stream herbivore movement. Philosophical Transactions of The Royal Society B-Biological Sciences 2007 doi: 10.1098/rstb.2006.1974

Olson D, Andow D: Patch edges and insect populations. Oecologia 2008 doi: 10.1007/s00442-0070933-6

Ord $\mathrm{Tj}$, Emblen J, Hagman $\mathrm{M}$, Shofner $\mathrm{R}$, Unruh S: Manipulation of habitat isolation and area implicates deterministic factors and limited neutrality in community assembly. Ecology And Evolution 2017 doi: 10.1002/ece3.3126

Orrock Jl, Curler Gr, Danielson Bj, Coyle Dr: Large-scale experimental landscapes reveal distinctive effects of patch shape and connectivity on arthropod communities. Landscape Ecology 2011 doi: 10.1007/s10980-011-9656-5

Orrock Jl,Danielson Bj,Burns Mj,Levey Dj: Spatial ecology of predator-prey interactions: Corridors and patch shape influence seed predation. Ecology 2003 doi: 10.1890/02-0439

Osborne Jl, Williams Ih: Site constancy of bumble bees in an experimentally patchy habitat. Agriculture Ecosystems \& Environment 2001 doi: 10.1016/S0167-8809(00)00262-0

O'Sullivan D, Benton Tg, Cameron Tc: Inter-patch movement in an experimental system: the effects of life history and the environment. Oikos 2014 doi: 10.1111/j.1600-0706.2013.01150.x

Parker $M$, Mac Nally R: Habitat loss and the habitat fragmentation threshold: an experimental evaluation of impacts on richness and total abundances using grassland invertebrates. Biological Conservation 2002 doi: 10.1016/S0006-3207(01)00184-7

Parsche S, Frund J, Tscharntke T: Experimental environmental change and mutualistic vs. antagonistic plant flower-visitor interactions. Perspectives In Plant Ecology Evolution And Systematics 2011 doi: 10.1016/j.ppees.2010.12.001

Pedruski Mt, Arnott Se: The effects of habitat connectivity and regional heterogeneityon artificial pond metacommunities. Oecologia 2011 doi: 10.1007/s00442-010-1814-y

Perdomo G, Sunnucks $\mathrm{P}$, Thompson $\mathrm{Rm}$ : The role of temperature and dispersal in mossmicroarthropod community assembly after a catastrophic event. Philosophical Transactions of The Royal Society B-Biological Sciences 2012 doi: 10.1098/rstb.2012.0241

Pierri-Daunt Ab, Tanaka Mo: Assessing habitat fragmentation on marine epifaunal macroinvertebrate communities: an experimental approach. Landscape Ecology 2014 doi: 10.1007/s10980-013-9970-1

Pitcher Ka, Soluk Da: Fish presence and inter-patch connectivity interactively alter the size of emergent insects in experimental enclosures. Ecosphere 2018 doi: 10.1002/ecs2.2118

Quintero I, Rosslin T: Rapid recovery of dung beetle communities following habitat fragmentation in centrl amazonia. Ecology 2005 doi: doi.org/10.1890/04-1960 
Rantalainen Ml, Fritze H, Haimi J, Pennanen T, Setala H: Species richness and food web structure of soil decomposer community as affected by the size of habitat fragment and habitat corridors. Global Change Biology 2005 doi: 10.1111/j.1365-2486.2005.00999.x

Rantalainen Ml, Kontiola L, Haimi J, Fritze H, Setala H: Influence of resource quality on the composition of soil decomposer community in fragmented and continuous habitat. Soil Biology \& Biochemistry 2004 doi: 10.1016/j.soilbio.2004.05.017

Rantalainen Ml,Haimi J,Fritze $\mathrm{H}$,Setala $\mathrm{H}$ : Effects of small-scale habitat fragmentation, habitat corridors and mainland dispersal on soil decomposer organisms. Applied Soil Ecology 2006 doi: 10.1016/j.apsoil.2006.03.004

Rantalainen Ml,Haimi J,Setala $\mathrm{H}$ : Testing the usefulness of habitat corridors in mitigating the negative effects of fragmentation: the soil faunal community as a model system. Applied Soil Ecology 2004 doi: 10.1016/j.apsoil.2003.09.004

Rauch G, Weisser Ww: Local and spatial dynamics of a host-parasitoid system in a field experiment. Basic And Applied Ecology 2006 doi: 10.1016/j.baae.2006.03.007

Reed $\mathrm{Bj}$, Hovel Ka: Seagrass habitat disturbance: how loss and fragmentation of eelgrass Zostera marina influences epifaunal abundance and diversity. Marine Ecology Progress Series 2006 doi: $10.3354 /$ meps326133

Reeve Jd, Cronin Jt: Edge behaviour in a minute parasitic wasp. Journal Of Animal Ecology 2010 doi: 10.1111/j.1365-2656.2009.01640.x

Rego Fnaa, Venticinque Em, Brescovit Ad: Effects of forest fragmentation on four Ctenus spider populations (Araneae: Ctenidae) in central Amazonia, Brazil. Studies On Neotropicalfauna And Environment 2007 doi: 10.1080/01650520600935082

Resasco J, Haddad N, Orrock Jl, Schoemaker Dw, Brudvig La, Damschen Ei, Tewksbury Jj, Levey $\mathrm{Dj}$ : Landscape corridors can increase invasion by an exotic species and reduce diversity of native species. Ecology 2014 doi: 10.1890/14-0169.1

Resasco J, Levey $\mathrm{Dj}$, Damschen Ei: Habitat corridors alter relative trophic position of fire ants. Ecosphere 2012 doi: 10.1890/ES12-00266.1

Resetarits $\mathrm{Wj}$, Binckley $\mathrm{Ca}$ : Spatial contagion of predation risk affects colonization dynamics in experimental aquatic landscapes. Ecology 2009 doi: 10.1890/08-0613.1

Resetarits Wj, Binckley Ca: Patch quality and context, but not patch number, drive multi-scale colonization dynamics in experimental aquatic landscapes. Oecologia 2013 doi: 10.1007/s00442013-2644-5

Roberts Da,Poore Agb: Habitat configuration affects colonisation of epifauna in a marine algal bed. Biological Conservation 2005 doi: 10.1016/j.biocon.2005.07.010

Romero S, Campbell Jf, Nechols Jr, With Ka: Movement behavior in response to landscape structure: the role of functional grain. Landscape Ecology 2009 doi: 10.1007/s10980-008-9278-8 
Rusterholz H-P, Baur B: Delayed response in a plant-pollinator system to experimental grassland fragmentation. Oecologia 2010 doi: 10.1007/s00442-010-1567-7

Schamp Bs, Arnott Se, Joslin KI: Dispersal strength influences zooplankton co-occurrence patterns in experimental mesocosms. Ecology 2015 doi: 10.1890/14-1128.1

Schooley RI, Wiens Ja: Finding habitat patches and directional connectivity. Oikos 2003 doi: 10.1034/j.1600-0706.2003.12490.x

Schooley R,Wiens Ja: Movements of cactus bugs: patch transfers, matrix resistance, and edge permeability. Landscape Ecology 2004 doi: 10.1007/s10980-005-0093-2

Schuler Ms, Chase Jm, Knight Tm: Habitat patch size alters the importance of dispersal for species diversity in an experimental freshwater community. Ecology And Evolution 2017 doi: 10.1002/ece3.2858

Schulke B, Waser Nm: Long-distance pollinator flights and pollen dispersal between populations of Delphinium nuttallianum. Oecologia 2001 doi: 10.1007/s004420000586

Searle $\mathrm{Kr}$, Hobbs $\mathrm{Nt}$, Jaronski St: Asynchrony, fragmentation, and scale determine benefits of landscape heterogeneity to mobile herbivores. Oecologia 2010 doi: 10.1007/s00442-010-1610-8

Shinomiya Y,Chiba S,Kanamori M,Hashizume S,Yoshino K,Goshima S: Importance of patch size variation for the population persistence of a decapod crustacean in seagrass beds. Marine Ecology Progress Series 2017 doi: 10.3354/meps12126_

Shirley Mdf,Sibly Rm: Metapopulation dynamics of fruit flies undergoing evolutionary change in patchy environments. Ecology 2001 doi: 10.2307/2679849

Shurin Jb: Interactive effects of predation and dispersal on zooplankton communities. Ecology 2001 doi: 10.1890/0012-9658(2001)082[3404:IEOPAD]2.0.CO;2

Silver P, Cooper Jk, Palmer Ma, Davis Ej: The arrangement of resources in patchy landscapes: effects on distribution, survival, and resource acquisition of chironomids. Oecologia 2000 doi: $10.1007 / \mathrm{s} 004420050009$

Staddon P,Lindo Z,Crittenden Pd,Gilbert F,Gonzalez A: Connectivity, non-random extinction and ecosystem function in experimental metacommunities. Ecology Letters 2010 doi: 10.1111/j.14610248.2010.01450.x

Starzomski Bm, Srivastava Ds: Landscape geometry determines community response to disturbance. Oikos 2007 doi: 10.1111/j.0030-1299.2007.15547.x

Stasek Dj, Radl Jn, Crist To: The Effects of Dispersal and Predator Density on Prey Survival in an Insect-Red Clover Metacommunity. Journal Of Insect Science 2017 doi: 10.1093/jisesa/iex100

Steffan-Dewenter I, Tscharntke T: Effects of habitat isolation on pollinator communities and seed set. Oecologia 1999 doi: 10.1007/s004420050949

Steiner Cf, Stockwell Rd, Kalaimani V, Aqel Z: Population synchrony and stability in environmentally forced metacommunities. Oikos 2013 doi: 10.1111/j.1600-0706.2012.20936.x 
Steiner Cf,Stockwell Rd,Kalaimani V,Aqel Z: Dispersal Promotes Compensatory Dynamics and Stability in Forced Metacommunities. American Naturalist 2011 doi: 10.1086/660835

Stoll P, Dolt C, Goverde M, Baur B: Experimental habitat fragmentation and invertebrate grazing in a herbaceous grassland species. Basic And Applied Ecology 2006 doi: 10.1016/j.baae.2005.09.001

Strecker Al, Arnott Se: Complex interactions between regional dispersal of native taxa and an invasive species. Ecology 2010 doi: 10.1890/08-0065.1

Sullivan LI, Johnson Bl, Brudvig La, Haddad Nm: Can dispersal mode predict corridor effects on plant parasites?. Ecology 2011 doi: 10.1890/10-1116.1

Summerville Ks, Crist To: Effects of experimental habitat fragmentation on patch use by butterflies and skippers (Lepidoptera). Ecology 2001 doi: 10.1890/0012-9658(2001)082[1360:EOEHFO]2.0.CO;2

Summerville Ks, Veech Ja, Crist To: Does variation in patch use among butterfly species contribute to nestedness at fine spatial scales?. Oikos 2002 doi: 10.1034/j.1600-0706.2002.970205.x

Sweatman Jl,Layman Ca,Fourqurean JW: Habitat fragmentation has some impacts on aspects of ecosystem functioning in a sub-tropical seagrass bed. Marine Environmental Research 2017 doi: 10.1016/j.marenvres.2017.02.003

Symons Cc, Arnott Se: Regional zooplankton dispersal provides spatial insurance for ecosystem function. Global Change Biology 2013 doi: 10.1111/gcb.12122

Thompson $\mathrm{Pl}$, Shurin Jb: Regional zooplankton biodiversity provides limited buffering of pond ecosystems against climate change. Journal Of Animal Ecology 2012 doi: 10.1111/j.13652656.2011.01908.x

Townsend Pa,Levey $\mathrm{Dj}$ : An experimental test of whether habitat corridors affect pollen transfer. Ecology 2005 doi: 10.1890/03-0607

Trekels H, Van De Meutter F, Stoks R: Habitat isolation shapes the recovery of aquatic insect communities from a pesticide pulse. Journal Of Applied Ecology 2011 doi: 10.1111/j.13652664.2011.02053.x

Warry Fy, Hindell Js, Macreadie Pi, Jenkins Gp, Connolly Rm: Integrating edge eVects into studies of habitat fragmentation: a test using meiofauna in seagrass. Oecologia 2009 doi: 10.1007/s00442008-1258-9

Watts Ch, Didham Rk: Influences of habitat isolation on invertebrate colonization of Sporadanthus ferrugineus in a mined peat bog. Restoration Ecology 2006 doi: 10.1111/j.1526-100X.2006.00149.x

Wells Cn,Williams Rs,Walker Gl,Haddad Nm: Effects of Corridors on Genetics of a Butterfly in a Landscape Experiment. Southeastern Naturalist 2009 doi: 10.1656/058.008.0412

With Ka: Are landscapes more than the sum of their patches?. Landscape Ecology 2016 doi: 10.1007/s10980-015-0328-8

With Ka, Cadaret Sj, Davis C: Movement responses to patch structure in experimental fractal landscapes. Ecology 1999 doi: 10.1890/0012-9658(1999)080[1340:MRTPSI]2.0.CO;2 
With Ka, Pavuk Dm: Habitat area trumps fragmentation effects on arthropods in an experimental landscape system. Landscape Ecology 2011 doi: 10.1007/s10980-011-9627-x

With Ka, Pavuk Dm: Direct versus indirect effects of habitat fragmentation on community patterns in experimental landscapes. Oecologia 2012 doi: 10.1007/s00442-012-2325-9

With Ka, Pavuk Dm, Worchuck Jl, Oates Rk, Fisher Jl: Threshold effects of landscape structure on biological control in agroecosystems. Ecological Applications 2002 doi: 10.1890/10510761(2002)012[0052:TEOLSO]2.0.CO;2

Zaviezo T, Grez Aa, Estades Cf, Perez A: Effects of habitat loss, habitat fragmentation, and isolation on the density, species richness, and distribution of ladybeetles in manipulated alfalfa landscapes. Ecological Entomology 2006 doi: 10.1111/j.1365-2311.2006.00830.x

Zschokke S, Dolt C, Rusterholz Hp, Oggier P, Braschler B, Thommen Gh, Ludin E, Erhardt A, Baur B: Short-term responses of plants and invertebrates to experimental small-scale grassland fragmentation. Oecologia 2000 doi: $10.1007 /$ s004420000483

Zurbuchen A,Cheesman S,Klaiber J,Muller A,Hein S,Dorn S: Long foraging distances impose high costs on offspring production in solitary bees. Journal Of Animal Ecology 2010 doi: 10.1111/j.13652656.2010.01675.x 